\title{
É POSSÍVEL UTILIZAR OS DIREITOS DAS GESTANTES COMO FORMA DE CONCRETIZAR UM MEIO AMBIENTE DO TRABALHO SAUDÁVEL? UMA ANÁLISE DA LEGISLAÇÃO EXISTENTE SOBRE O TEMA E DAS MUDANÇAS ADVINDAS COM A REFORMA TRABALHISTA*
}

\author{
Luisa da Rosa Moccellin** \\ Maria Claudia Felten***
}

\section{RESUMO}

0 artigo em questão visa analisar os direitos concedidos às mulheres gestantes, bem como as mudanças ocorridas em tais garantias com a aprovação da Reforma Trabalhista, Lei n 13.467/2017, que entrou em vigor em 11 de novembro de 2017. Também serão estudadas alterações que poderiam ter ocorrido no ordenamento como forma de trazer mais segurança jurídica às relações trabalhistas, especificamente a falta de regulamentação no que concerne ao prazo em que a gestante com estabilidade pode ingressar com ação judicial requerendo sua reintegração ao emprego. Ainda, será analisado o período de 120 dias de licença-maternidade atualmente concedido às mulheres, buscando auferir se tal intervalo de tempo é suficiente para garantir uma amamentação adequada aos recémnascidos. Por fim, será discutida a novidade introduzida pela reforma trabalhista, que passou a admitir que as gestantes continuem trabalhando nos locais insalubres em grau médio e mínimo, sendo afastadas, apenas, em caso de apresentação de atestado de médico de confiança da mulher

* Artigo apresentando ao Curso de Direito do Centro Universitário Metodista - IPA, na área de concentração do Direito do Trabalho como requisito parcial para obtenção do grau de Bacharela em Direito.

** Graduanda do Curso de Bacharelado em Direito do Centro Universitário Metodista - IPA.

*** Orientadora do artigo, Doutora em Direito e professora do Curso de Bacharelado em Direito do Centro Universitário Metodista - IPA. 
que recomende o afastamento. 0 objetivo do presente estudo, realizado através de pesquisa bibliográfica e jurisprudencial, bem como pesquisa de campo com médicos ginecologistas, obstetras e pediatras é analisar se ocorreram avanços ou retrocessos nos direitos que as mulheres gestantes possuem atualmente no ordenamento jurídico, assim como discutir possíveis mudanças que contribuiriam para um aperfeiçoamento da legislação trabalhista. Essas questões inerentes às gestantes serão analisadas sobre o prisma do meio ambiente do trabalho, buscando observar se tais disposições realmente são capazes de concretizar um meio ambiente do trabalho seguro e saudável.

Palavras-chave: Gestantes. Reforma Trabalhista. Insalubridade. Amamentação e Licença-maternidade. Estabilidade da gestante. Mercado de Trabalho da Mulher.

\section{IS IT POSSIBLE TO ACHIEVE A HEALTHY WORKPLACE FROM LEGAL RIGHTS FOR PREGNANT WORKERS? AN ANALYSYS ON THE EXISTENT LEGISLATION AND THE CHANGES RESULTED FROM THE LABOR REFORM}

\section{ABSTRACT}

This paper aims to analyze the rights granted to pregnant women, as well as alterations to such garanteed rights as of the approval of the Labor Reform, Law no. 13.467/2017, which came in force in November, 11 of 2017. It will also study alterations that could have been applied in said amendment as to bring better legal safety to labor relations, specifically the lack of regulation concerning the time within which the pregnant worker with stability is able to file a lawsuit requiring her reintegration to the job. Futhermore, this study will also analyze whether the 120-day period of maternity leave currently granted to women is enough to garantee a quality breast-feeding for their newborns. Lastly, this paper will discuss one aspect of the new Amendment which started to allow pregnant women to continue working in unhealthy enviroments of medium and minimum level, being withdrawn from work only in case of medical reccomendation. The goal of this study, which is based on bibliographic and jurisprudence research, as well as field research in consultation of gynecologists, obstetricians and pediatricians, is to analyze whether advancements or setbacks were made in rights women hold in the legal department, as well as discuss possible changes that could contribute to improve labor legistation. Said issues inherent to pregnant women will be analyzed under the light of work environment, seeking to observe whether 
such provisions are truly capable of promoting a safe, healthy workplace.

Keywords: Pregnancy. Labor Reform. Unhealthiness. Breast-feeding and maternity leave. Pregnant stability. Women's Job Market.

\section{INTRODUÇÃO}

0 presente trabalho visa analisar os direitos que as mulheres gestantes detêm, assim como as mudanças ocorridas nestes direitos com a aprovação da Reforma Trabalhista. Além disso, serão estudadas certas "lacunas" legislativas, que poderiam ter sido preenchidas com a reforma ocorrida, a exemplo da falta de regulamentação com relação ao período em que as gestantes podem requerer sua reintegração ao constatarem a gravidez após a demissão, na medida em que o empregador sempre possui o dever de reintegrar a empregada grávida, mesmo que não soubesse da gestação.

Não obstante, o fato de a gestante poder ingressar com a ação a qualquer tempo limita o direito de reintegração ao emprego, fazendo com que em alguns casos, a única alternativa ao empregador seja a indenização, de forma em que é perpetuado um abuso de direito por parte de muitas trabalhadoras que ajuízam a demanda após exaurido o período de estabilidade, visando a obtenção apenas da indenização.

A legislação existente sobre a estabilidade da gestante será analisada sob o prisma do meio ambiente do trabalho, matéria que visa a saúde dos trabalhadores. Para tanto, determina a realização de exames, a utilização de equipamentos de proteção, entre outros, para a concretização de um ambiente saudável. Será pesquisada a possibilidade de inserção do teste de gravidez dentre os exames demissionais. Ele pode ser utilizado como forma de concretizar o direito a reintegração da mulher grávida ao seu emprego, proporcionando a possibilidade de escolha ao empregador entre a reintegração ou a indenização da gestante e evitando abuso de direito por parte de empregadas mal intencionadas, que buscavam esperar o prazo de estabilidade passar 
para requerer apenas o valor da indenização, recebendo o mesmo ainda com juros de mora.

De outra banda, dentro da legislação trabalhista acerca das gestantes, será analisado o período de 120 dias concedidos para a licença da empregada grávida ter o seu filho e o amamentar e cuidar neste primeiro período de vida da criança, e de 180 dias, caso o empregador tenha aderido ao Programa da Empresa Cidadã e seja do interesse da gestante usufruir período maior.

De acordo com as orientações do Ministério da Saúde com relação ao período de amamentação mínimo, os dias de licença poderiam ser estendidos como forma de melhorar a qualidade de vida da mãe e da criança, concretizando, mais uma vez, um meio ambiente do trabalho saudável.

0 texto da reforma trabalhista alterou sensivelmente o trabalho da mulher gestante em locais insalubres, que anteriormente era totalmente proibido e, atualmente, as mulheres grávidas poderão laborar em locais insalubres em grau médio ou mínimo, possuindo o direito de se afastar somente mediante atestado médico indicando a necessidade de fazê-lo. Serão analisadas as consequências que podem ser implicadas para a saúde da mulher gestante submetida a estas condições.

0 tema do presente trabalho é extremamente relevante para a sociedade como um todo, tendo em vista que através das mulheres ocorre a perpetuação da espécie humana. 0 momento gestacional, o parto e os primeiros meses de vida da criança se tratam de um momento extremamente delicado, fazendo-se imensamente necessário que o Direito destine uma tutela diferenciada para aqueles que se encontram nesta situação.

Contudo, a proteção jurídica não pode albergar também formas passíveis de abuso de direito, como ocorre com a possibilidade de a mulher grávida demitida não necessitar avisar o seu empregador de que se encontra nesta condição, o que, muitas vezes acaba preterindo o direito do empregador de reintegrar à 
gestante ao emprego e contar com sua força de trabalho, restando como única alternativa a indenização.

Desta forma, esse tema interessa tanto aos trabalhadores, como aos empregadores, tendo em vista que se busca um ponto de equilíbrio entre os direitos da gestante e do empregador. Com relação aos trabalhadores, serão discutidas as condições necessárias para um meio ambiente do trabalho saudável, verificando as consequências que poderão ser advindas com a Reforma Trabalhista, que autorizou o trabalho insalubre em grau médio e mínimo das gestantes, bem como será discutido o período mínimo de licença-maternidade atualmente concedido.

Por conseguinte, trata-se de um tema inovador, tendo em vista a recente aprovação do projeto da reforma trabalhista, mas que busca também dialogar com a legislação antiga, sendo, portanto extremamente relevante para a comunidade acadêmica, bem como para a sociedade como um todo, conforme anteriormente referido.

Para a confecção do trabalho foi utilizada a pesquisa bibliográfica, descritiva e jurisprudencial. Também foi utilizado o método qualitativo para a realização de entrevistas com médicos ginecologistas, obstetras e pediatras para analisar o pensamento de profissionais da área com relação ao trabalho da gestante em local insalubre e suas consequências.

Os resultados obtidos serão apresentados a seguir, divididos nos seguintes tópicos: "2. O mercado de trabalho da mulher e suas particularidades", onde será demonstrada a necessidade, em alguns casos, de se ter uma legislação diferenciada com relação às mulheres, principalmente no que tange à maternidade; "3. $A$ estabilidade da gestante, o meio ambiente do trabalho e o abuso de direito", onde será analisada a falta de regulamentação com relação à informação da gravidez ao empregador e suas implicações; "4. A extensão do período de licença-maternidade como forma de efetivação de um meio ambiente do trabalho saudável", onde será 
discutida a possibilidade de ampliação da licença-maternidade; e "5. Das mudanças advindas com a reforma trabalhista: possibilidade das gestantes trabalharem em ambientes insalubres", seção em que analisaremos as consequências da reforma trabalhista para as mulheres gestantes.

\section{O MERCADO DE TRABALHO DA MULHER E SUAS PARTICULARIDADES}

Os princípios têm papel marcante para o Direito do Trabalho, especialmente o Princípio da Proteção, o qual norteia os diversos tipos de relação de trabalho.

No que concerne às gestantes, também existem dispositivos que visam proteger este importante momento de constituição da vida. Além disso, tais previsões possuem o escopo de proteção ao trabalho da mulher, tendo em vista que durante muitos anos as mulheres foram consideradas inaptas ao mercado de trabalho, na medida em que recebiam a responsabilidade de tutela dos filhos e do lar.

Neste sentido, leciona Maria Ines Moura S. A. da Cunha:

Remonta à Antiguidade a chamada divisão sexual das tarefas, fenômeno que ainda hoje presenciamos, mas de forma mitigada. [...]. Embora existam registros da igualdade de tratamento entre homens e mulheres no que tange às atividades por ambos exercidas, notadamente na sociedade cretense, na Grécia antiga, e mesmo em Roma, onde se vê inclusive o acesso à literatura, à filosofia e às artes, nos séculos X a XIV, a despeito da existência de profissões comuns a homens e mulheres, os salários destas vão-se distanciando dos salários masculinos. No Renascimento, as mulheres deixam várias profissões, até restarem confinadas ao trabalho doméstico. De tal situação serão retiradas no século XIX, quando sua mão-de-obra vai ser solicitada pelas fábricas inglesas e francesas, por ser menos dispendiosa. (CUNHA, 2004, p. 188). 
De acordo com Celestino et al. (1997, p. 61) após a Revolução Industrial foi desenvolvido o maquinário, o que reduziu o esforço muscular e introduziu a mão-de-obra feminina em larga escala, até mesmo preterindo o trabalho masculino, tendo em vista que a mulher ganhava menos e possuía uma jornada de trabalho maior. No século XIX, após a pressão operária e atuação de alguns governantes, foram editadas medidas de proteção à mulher, 0 que foi feito com vistas a impedir o desemprego masculino, na medida em que os empresários estavam optando pela exploração desenfreada de mulheres e crianças.

Conforme estudo de Bento Herculano Duarte Neto (2018, p. 162 , 163), a primeira constituição brasileira, a imperial de 1824, considerava cidadãos apenas os homens, as mulheres não podiam votar e ser votadas, nem exercer empregos ou cargos públicos. A constituição de 1934 foi a primeira a tratar sobre o trabalho da mulher, positivando alguns direitos das gestantes inclusive, tendo em vista que foi inspirada nas constituições do México, de 1917, e da Alemanha (Weimar), de 1919. Nesta época, assim como durante a vigência da constituição de 1937 e 1946, as mulheres eram proibidas de trabalhar em ambientes insalubres. Vale ressaltar que a constituição de 1946 trouxe a proibição de diferença salarial por motivo de sexo. Seguindo, a constituição de 1967 diminuiu o tempo de aposentadoria feminina para 30 anos de serviço.

Com relação à atual constituição e a igualdade entre homens e mulheres, o autor discorre:

A constituição federal de 1988, em seu artigo 5ํㅜ, I, assegura que homens e mulheres são iguais em direitos e obrigações. Todavia, o referido preceito constitucional não impede que o Poder Público, por meio de ações afirmativas, estabeleça um tratamento diferenciado às mulheres diante das desigualdades históricas existentes de suas limitações, decorrentes da própria natureza, em busca 
de se promover a tão almejada igualdade material, em uma perspectiva aristotélica, sem que isso se configure ofensa ao princípio da isonomia. (NETO, 2018, p.163).

Deste modo, com o advento da mulher ao mercado de trabalho e a verificação das particularidades que enfrentam, surgiram previsões de tratamento diferenciado para elas, questões reguladas, sobretudo, pela manutenção de um meio ambiente do trabalho saudável.

Conforme Celestino et al.:

Reconhecendo que a participação das mulheres, inclusive as casadas, na força de trabalho é uma realidade incontestável, as primeiras providências tomadas pelos organismos internacionais visavam a proteger a gravidez e a maternidade. (CELESTINO et al., 1997, p. 61).

De acordo com Nascimento (2011, p. 845), a proteção do meio ambiente do trabalho está baseada na seguinte premissa: para que o trabalhador atue em local apropriado, o direito deve fixar condições mínimas a serem observadas pelas empresas, quer quanto às instalações, quer quanto às condições de contágio com agentes nocivos à saúde ou perigo que a atividade possa oferecer.

Assim, surgem normas que diferenciam o tratamento dos homens e mulheres empregados, contudo, tais normas não buscam um tratamento desigual entre os sexos, mas sim uma igualdade material diante das particularidades de cada um. Como exemplo, é possível observar a redação do art. 390 da Consolidação das Leis do Trabalho - CLT, que dispõe que o peso máximo que a empregada mulher pode carregar é de $20 \mathrm{~kg}$ para o trabalho contínuo e $25 \mathrm{~kg}$ para o trabalho ocasional, enquanto o peso máximo que os empregados homens podem suportar é de $60 \mathrm{~kg}$, conforme o art. 198, da mesma legislação. Neste sentido, é indiscutível a 
existência de uma diferença de natureza biológica entre os sexos, fazendo com que seja necessária, em algumas oportunidades, a intervenção do legislador para que se tenha um tratamento efetivamente igualitário para as mulheres.

Este trabalho propõe-se a analisar as disposições existentes na legislação trabalhista que diferenciam e possibilitam o trabalho das mulheres no mercado de trabalho, especialmente sobre o viés da reforma trabalhista, que trouxe algumas alterações neste sentido, sendo que a maioria delas prejudica os direitos adquiridos por estas mulheres ao longo dos anos, principalmente no que concerne à maternidade.

Por outro lado, existiam diferenciações na legislação entre homens e mulheres que já estavam ultrapassadas e foram alteradas pela reforma trabalhista, como o intervalo de quinze minutos que se exigia antes da mulher realizar horas extras, previsto no artigo 384 da CLT, atualmente revogado. 0 artigo revogado era fruto da época em que foi editado, que a mulher era considerada o "sexo frágil", que necessitava de uma maior proteção legislativa. Com a busca da igualdade dos homens e mulheres hoje, não fazia mais sentido.

Contudo, alguns doutrinadores também criticam esta mudança na legislação, como é o caso de Izabel Christina Baptista Queiróz Ramos. Segundo o pensamento da autora:

Com a nova dicção legal, e a revogação da referida norma de proteção, as mulheres deixam de ter o direito ao descanso, podendo ser exigido o trabalho delas além da jornada legal ou contratual, sem interrupção de quinze minutos.

Ocorre que o benefício previsto na CLT tem razão de ser, qual seja, o maior desgaste físico feminino com a dupla jornada que soma o trabalho na empresa e o doméstico, sem qualquer agressão ao princípio da igualdade, que não é absoluto e sempre admitiu exceções, desde que devidamente 
justificadas, para que não haja discriminação negativa. (RAMOS, 2018, p. 155).

No entanto, a razão de ser explanada pela autora para a existência da referida diferenciação não condiz com a modernidade, na medida em que cada vez mais se tem avançado com a divisão das tarefas domésticas entre homens e mulheres, representando tal norma um retrocesso. Ademais, é possível observar a redação do art. 226, §5ํㅡㄹ da CF, que dispõe que os direitos e deveres referentes à sociedade conjugal são exercidos igualmente pelo homem e pela mulher.

Não obstante, outros direitos destinados especificamente às mulheres fazem-se extremamente necessários, como a previsão da licença-maternidade, onde a gestante pode permanecer afastada de suas funções sem prejuízo de seu salário e emprego por um período de 120 dias, conforme dispõem o art. 7ํㅡ, inciso XVIII, da Constituição Federal - CF e o art. 392, da CLT. Nesse caso também se tratam de normas que buscam regular uma diferença biológica de forma a não prejudicar as mulheres no mercado de trabalho.

0 referido artigo da Consolidação das Leis do Trabalho garante a gestante o direito de comparecer em, no mínimo, seis consultas médicas e demais exames complementares durante o horário de trabalho, sem descontos salariais. 0 cônjuge ou companheiro da gestante, por sua vez, tem direito de se afastar do trabalho por dois dias para acompanhar a esposa nas consultas e exames, de acordo com o art. 473, inciso X, da CLT.

Como discorre Celestino et al. (1997, p. 63), o papel da mulher no mundo social modificou-se, porém sua função fisiológica de procriação não se alterou, não obstante as técnicas modernas de inseminação artificial, o que justifica as medidas de proteção e seu aperfeiçoamento. Tais medidas não são discriminatórias, mas sim protetivas da saúde da mulher e das futuras gerações.

Nesta seara, verifica-se a importância da tutela diferenciada entre homens e mulheres, possibilitando a ambos o ingresso e permanência no mercado de trabalho, com a garantia de manutenção de um meio ambiente do trabalho saudável. 
Nesse sentido, discorre Zélia Maria Cardoso Montal:

De fato, a ordem jurídica confere proteção especial ao trabalho da mulher, especialmente no que concerne à gestação e à maternidade, evitando-se, assim, a discriminação em razão de gênero, havendo proibição do trabalho em determinadas atividades e restrição quanto à prorrogação excessiva da jornada de trabalho. (MONTAL, 2017, p. 127).

No tocante a análise que será feita sobre a reforma trabalhista, é importante ressaltar a procura, no presente trabalho, de equilíbrio com relação às críticas às mudanças, bem como às disposições já existentes na CLT sobre as gestantes, sempre buscando dados e informações científicas. Logicamente é difícil ocorrer a isenção total do escritor, mas o posicionamento adotado busca o compromisso com ambas as partes da relação de emprego, preservando a Justiça Trabalhista.

Nesse sentido, citamos o importante posicionamento de Raymundo Pinto:

Há que se reconhecer que as discussões em torno do assunto pecam, sobretudo, por tomar caminhos bastante comprometidos com radicais opiniões eivadas de sentimentos emotivos ou de tendências preconceituosas por força de posições ideológicas e partidárias. Por causa disso, existem os que acham ter sido a reforma criada "para acabar com os direitos dos trabalhadores" e outros, muito governistas, que nela só veem vantagens e até lhe atribuem ser a solução para o atual elevado desemprego. Descontados os exageros e na tentativa de buscar o equilíbrio, é possível afirmar-se que a Lei 13.467, de 13.7.2017, introduziu, na verdade, alterações prejudiciais à classe trabalhadora, mas contém aspectos positivos, como se verá adiante. (PINTO, 2018, p. 21). 
Partindo-se dessa premissa, serão feitas as considerações a seguir sobre os direitos existentes em nosso ordenamento jurídico com relação às mulheres que se encontram no período gestacional.

\section{A ESTABILIDADE DA GESTANTE, O MEIO AMBIENTE DO TRABALHO E O ABUSO DE DIREITO}

Como referido, a licença-maternidade está prevista no art. 7ํㅗ , inciso XVIII, da CF e no art. 392, da CLT. Segundo estes dispositivos, a gestante pode permanecer afastada de suas funções sem prejuízo de seu salário e emprego por um período de 120 dias, podendo ser prorrogado por mais 60 dias, sendo, daí, de 180 dias, quando a empresa aderiu ao Programa da Empresa Cidadã. Para a concessão de sua licença, a empregada deverá notificar seu empregador através de atestado médico sobre a data de início do afastamento do trabalho, que poderá ocorrer entre o $28^{\circ}$ dia antes do parto e o próprio parto.

Durante este delicado período de gravidez e concessão de licença-maternidade, a mulher possui garantia no emprego, ficando vedada a dispensa arbitrária ou sem justa causa desde a confirmação da gravidez até cinco meses após o parto, conforme o art. 10, inciso II, alínea b, do Ato das Disposições Constitucionais Transitórias, bem como determina a Súmula 244, do Tribunal Superior do Trabalho - TST.

Tal garantia se justifica plenamente pelos seguintes motivos:

A gravidez é uma fase que provoca profundas modificações na mulher. Modificações de ordem física e psicológica. No período gestacional a mulher fica mais sensível, mais vulnerável, sujeita a variações constantes de humor. Podem surgir nela dúvidas, medos, fantasias. Afinal, ela é diretamente responsável por uma nova vida. (BRAIANI, 2005, p.168).

Conforme Celestino et al.: 
0 direito da estabilidade à gestante consagrado no art. 10, II, "b", do ADCT da Lex Fundamentalis de 1988 não é inédito, mas não era reconhecido na legislação anterior a ela. Este tipo de garantia só era previsto anteriormente no Direito Coletivo, surgindo por meio das convenções coletivas de trabalho das categorias mais fortes, experimentando um processo bastante rápido da generalização entre as profissões. Logo, atualmente, a estabilidade da gestante é legal, absoluta e provisória. (CELESTINO et al., 1997, p. 70).

Para Braiani (2005, p. 168) a empregada detentora de estabilidade possui direito à manutenção do emprego, podendo ser demitida apenas por justa causa ou quando ocorrer o encerramento das atividades do empregador, pela impossibilidade material.

Cumpre frisar que, caso a mulher seja dispensada sem justa causa, mesmo que o empregador não soubesse de seu estado gravídico, será obrigado a reintegrá-la aos quadros da empresa assim que a mulher lhe comunicar sobre a gravidez ou realizar o pagamento dos salários referentes ao período de estabilidade. Conforme Braiani (2005, p. 170), a empregada deverá comprovar, por qualquer meio legítimo, que à época da dispensa já havia "confirmado" seu estado gestacional.

Ainda de acordo com Celestino et al. (1997, p. 64), existiam duas correntes acerca da necessidade de conhecimento da gravidez pelo empregador: a concepção subjetivista, segundo a qual o conhecimento do estado gravídico pelo patrão quando da dispensa imotivada é necessário para que se possa atribuir malícia ao ato resitiório e a consequente responsabilidade pelo pagamento do período referente à licença; e a concepção objetivista, que preceitua que a garantia de emprego está condicionada à confirmação objetiva da gravidez e não ao empregador. A teoria objetivista é a dominante em nosso ordenamento jurídico. 
A importância desta norma como uma garantia ao nascituro é extrema e indiscutível. Todavia, muitas mulheres demitidas durante o período de estabilidade, ao descobrirem a gravidez, silenciam sobre o assunto e somente ajuízam reclamatória trabalhista requerendo a indenização após exaurido o período gestacional, objetivando receber apenas os valores e excluindo a possibilidade de reintegração aos quadros da empresa.

Assim, uma norma realizada com o escopo de proteger o mercado de trabalho da mulher de forma justa, acaba sendo utilizada de forma injusta por algumas empregadas que promovem um abuso de direito ao não permitir ao empregador o direito de reintegrá-las.

Com relação ao abuso de direito, conforme Braiani (2005, p. 171), existem duas teorias. A primeira relaciona o abuso de direito à culpa (presença do elemento intencional do agente). Já para a segunda teoria, ocorrerá o abuso de direito quando o mesmo for exercido de forma contrária aos seus fins sociais e econômicos. Concordamos com a segunda teoria, que se aplica perfeitamente ao caso em análise, tendo em vista que a finalidade da norma prevista no ADCT é a manutenção do emprego e, da forma como utilizada por algumas trabalhadoras, fica limitada à indenização substitutiva.

$\mathrm{Na}$ análise da jurisprudência, é possível encontrar decisões que não concedem o pagamento de indenização à mulher que ajuizou ação após exaurido o período de estabilidade, tendo em vista se tratar de abuso do direito de ação a demora injustificada em ajuizar a demanda. Há casos em que as empregadas ajuízam a ação muito tempo após o nascimento do filho, portanto a norma perde totalmente o seu sentido de proteção ao nascituro ${ }^{1}$.

Acórdão: 0021261-54.2015.5.04.0003 (RO) Redator: LAIS HELENA JAEGER NICOTTI Órgão julgador: 1a Turma Data: 06/07/2017. In: RIO GRANDE DO SUL. Tribunal Regional do Trabalho da 4a Região. Acórdão $\mathbf{n}^{\circ} \mathbf{0 0 2 1 2 6 1 -}$ 54.2015.5.04.0003. Primeira Turma. TRT4, Porto Alegre, 06 jul. 2017. Relatora Lais Helena Jaeger Nicotti. Disponível em: <https://www.trt4.jus. 
Indaga-se se é moralmente correto indenizar a mulher que ajuíza ação após decorrido o período estabilitário, com a única finalidade de receber indenização. Faz-se essa indagação fazendo um comparativo com aquela que ingressa na justiça, requerendo a reintegração e se colocando à disposição para retornar ao trabalho durante o período gestacional, face ao princípio da isonomia. É indubitável que o empregador se vê diante de um risco em

$\mathrm{br} / \mathrm{pesquisas} / \mathrm{rest} / \mathrm{cache} / \mathrm{ac}$ ordao/pje/41M9gg3ex5ud1NjX4BZnvg/?\&tp=gestante $+\mathrm{a} \% \mathrm{C} 3 \% \mathrm{~A} 7 \% \mathrm{C} 3 \% \mathrm{~A} 3 \mathrm{o}+\mathrm{ap} \% \mathrm{C} 3 \% \mathrm{~B} 3 \mathrm{~s}+\mathrm{a}+\mathrm{estabilidade}>$. Acesso em: 07 jun. 2018.

Acórdão: 0020586-80.2015.5.04.0233 (RO) Redator: MARIA HELENA LISOT

Órgão julgador: 11 1 a Turma Data: 25/05/2018. In: RIO GRANDE DO SUL. Tribunal Regional do Trabalho da 4⿳a Região. Acórdão $\mathbf{n}^{\circ} 0020586-$ 80.2015.5.04.0233. Décima Primeira Turma. TRT4, Porto Alegre, 25 maio 2018. Relatora Maria Helena Lisot. Disponível em: <https://www. trt4.jus.br/pesquisas/rest/cache/acor dao/pje/cbtCV8nbWkkRYwA7berW$3 \mathrm{~g}$ ?\&tp=gestante $+\mathrm{a} \% \mathrm{C} 3 \% \mathrm{~A} 7 \% \mathrm{C} 3 \% \mathrm{~A} 3 \mathrm{o}+\mathrm{ap} \% \mathrm{C} 3 \% \mathrm{~B} 3 \mathrm{~s}+\mathrm{a}+$ estabilidade $>$. Acesso em: 07 jun. 2018.

Acórdão: 0021654-11.2015.5.04.0251 (RO) Redator: IRIS LIMA DE MORAES Órgão julgador: 1a Turma Data: 31/08/2017. In: RIO GRANDE DO SUL. Tribunal Regional do Trabalho da 4⿳a a Região. Acórdão $\mathbf{n}^{\circ} 0021654$ 11.2015.5.04.0251. Primeira Turma. TRT4, Porto Alegre, 31 ago. 2017. Relatora Iris Lima de Moraes. Disponível em: <https://www.trt4.jus.br/ pesquisa s/rest/cache/acordao/pje/uUDlpupaltFq53XuzvrFPw?\&tp=gestante+indeniza $\% \mathrm{C} 3 \% \mathrm{~A} 7 \% \mathrm{C} 3 \% \mathrm{~A} 30+\mathrm{ap} \% \mathrm{C} 3 \% \mathrm{~B} 3 \mathrm{~s}+\mathrm{um}+\mathrm{ano}>$. Acesso em: 09 jun. 2018.

Acórdão: 0021284-84.2016.5.04.0772 (RO) Redator: LAIS HELENA JAEGER NICOTTI Órgão julgador: 1 ${ }^{a}$ Turma Data: 10/05/2018. In: RIO GRANDE DO SUL. Tribunal Regional do Trabalho da 4aㅡ Região. Acórdão n 002128484.2016.5.04.0772. Primeira Turma. TRT4, Porto Alegre, 10 maio 2018. Relatora Lais Helena Jaeger Nicotti. Disponível em: <https://www.trt4.jus. $\mathrm{br} /$ pesquisas /rest/cache/acordao/pje/zzPLldAo=4-yCG60X1GuWRA?\&qpgestante+ajuizamento+da+a $\% \mathrm{C} 3 \% \mathrm{~A} 7 \% \mathrm{C} 3 \% \mathrm{~A} 30+\mathrm{ap} \% \mathrm{C} 3 \% \mathrm{~B} 3 \mathrm{~s}+\mathrm{um}+\mathrm{ano}+-$ do+nascimento+do+filho>. Acesso em: 09 jun. 2018.

Acórdão: 0021378-05.2016.5.04.0102 (RO) Redator: LAIS HELENA JAEGER NICOTTI Órgão julgador: 1a Turma Data: 22/02/2018. In: RIO GRANDE DO SUL. Tribunal Regional do Trabalho da 4⿳亠丷a Região. Acórdão n 0021378 05.2016.5.04.0102. Primeira Turma. TRT4, Porto Alegre, 22 fev. 2018. Relatora Lais Helena Jaeger Nicotti. Disponível em: <https://www.trt4.jus. $\mathrm{br} /$ pesquisas/rest/cache/acor dao/pje/k4lZdnFPC2QRlu_jj5c6cg?\&qp=gestante+ajuizamento+da+a $\% \mathrm{C} 3 \% \mathrm{~A} 7 \% \mathrm{C} 3 \% \mathrm{~A} 3 \mathrm{o}+\mathrm{ap} \% \mathrm{C} 3 \% \mathrm{~B} 3 \mathrm{~s}+\mathrm{um}+\mathrm{ano}+\mathrm{do}+-$ nascimento+do+filho>. Acesso em: 09 jun. 2018. 
seu negócio. Portanto, para muitos, é menos arriscado contratar homens que não trarão este tipo de despesa. De acordo com o censo realizado em 2010 pelo Instituto Brasileiro de Geografia e Estatística, a taxa de atividade econômica dos homens é de 75,7\%, enquanto das mulheres é de $54,6 \%{ }^{2}$. Portanto, as pesquisas refletem a preferência dos empresários em contratar aqueles que lhes trarão mais lucro e menos despesas, pois essa é a dinâmica de toda atividade empresarial.

Pensando acerca de tais estatísticas, é possível refletir que seria bastante interessante a criação de normas de incentivo fiscal para a contratação de mulheres, tendo em vista que infelizmente ainda existe esse pensamento de que elas devem ganhar salários menores por causa da reprodução ou até mesmo nem serem contratadas.

Seguindo na análise da estabilidade da gestante, é indiscutível a necessidade desta norma para a proteção do nascituro e da mulher. Contudo, a legislação poderia ter sido modificada, neste sentido, para extinguir esta possibilidade de abuso de direito por parte das trabalhadoras e, consequentemente, fazer com que a contratação de mulheres não enseje riscos adicionais e desnecessários.

O jurista Francisco Antonio de Oliveira, citado por Celestino et al. (1997, p. 67), comentando a Súmula 244 do TST, afirma que o referido enunciado constitui mais um incentivo ao despedimento quando não permite a reintegração, indo além da vontade das partes. Para ele a empresa pode querer colocar o emprego à disposição, o que transferiria o ônus para a previdência, já que a

Taxa de atividade: quantifica o nível de pressão da PEA sobre o mercado de trabalho, através da relação entre o número de pessoas economicamente ativas e o número de pessoas em idade ativa (ambos com 16 anos ou mais de idade). In: INSTITUTO BRASILEIRO DE GEOGRAFIA E ESTATÍSTICA (IBGE). Estatísticas de Gênero. Brasília, DF: IBGE, 2010. Disponível em: <https:// www.ibge.gov.br/apps/snig/v1/?loc $=0$ \&cat $=-1,1,2,-2,-3,128 \&$ ind $=4727>$. Acesso em: 10 jun. 2018. 
gestante contribuiu para tanto. Alice Monteiro de Barros (2010, p. 1.114), discorre que o que se deve impor ao empregador, ao ser dispensada a empregada, é a reintegração no emprego, diante do fim perseguido pela norma. Nesta linha, José Augusto Rodrigues Pinto, citado por Celestino et. al. (1997, p. 70), comenta que, na prática, a estabilidade da gestante tem muito de relativa, ao passo que mediante a curta duração da mesma não permitirá a reintegração ao emprego antes de sua expiração, em face de reconhecida demora na tramitação dos processos judiciais, o que se resolve com a indenização substitutiva.

Chegou a ocorrer a proposição de alteração no que tange ao fato do empregador ser avisado ou não da gestação, em um dos primeiros projetos propostos para a reforma trabalhista. 0 que se pretendia era impor um prazo de trinta dias para a empregada demitida avisar seu empregador de que se encontrava em estado gravídico (LÁ VEM BEBÊ, 2018, paginação irregular; CASTRO, 2018, paginação irregular). Certamente tal solução não seria a mais adequada, pois não passou de uma proposta, não entrando em vigor na nova legislação trabalhista. 0 principal problema seria o prazo exíguo de trinta dias. Pensemos em uma gestação em estágio inicial, caso essa mulher não conseguisse constatar seu estado de gravidez dentro desses 30 dias perderia o seu direito, o que seria muito injusto e contrário às leis que já estavam em vigor, tendo em vista que o art. 10, II, "b", do ADCT preceitua que a gestante possui estabilidade desde a confirmação da gravidez, que pode ser retrógrada.

Emmanoel Pereira (2017, p. 38) cita um caso jurisprudencial (AIRR-1422400-38.2002.5.04.0900) onde foi estabelecido, em sede de convenção coletiva de trabalho, um prazo de 60 dias após o aviso prévio para a empregada demitida avisar da gestação para o gozo da estabilidade. Foi decidido que, havendo comando constitucional (art. 10, II, "b”, ADCT), não há como se admitir interpretação restritiva. Nesse ponto, realmente, como 
citamos acima, haveria ofensa ao princípio da isonomia, pois não é admissível conceder o direito para algumas e negar a outras. Esse julgado é um exemplo de que a concessão de prazo também não seria o mais adequado para a resolução desse problema do abuso do direito de estabilidade.

Atualmente, é proibida a realização de qualquer exame para a contratação e permanência de empregados, pois isso teria cunho preconceituoso e certamente as mulheres grávidas seriam ainda mais discriminadas, pois nenhum administrador adquiriria um "risco pronto" em seu negócio. Assim, a proibição de realização de exames, prevista nos arts. $1^{\circ}$ e $2^{\circ}$ da Lei 9.029 , de 1995 , é uma norma acertada, inclusive considerando crime práticas discriminatórias como esta.

Contudo, são realizados exames admissionais que verificam o estado de saúde do trabalhador, bem como demissionais. Trata-se aqui mais uma vez de normas para um meio ambiente do trabalho seguro.

Conforme Nascimento:

O acompanhamento da saúde do empregado é obrigação do empregador. Diversas obrigações a serem cumpridas pela empresa são previstas pela lei. Primeira, o exame médico, que é obrigatório, por conta do empregador, inclusive na admissão do empregado (CLT, art. 168). Será renovado anualmente; porém, nas atividades com insalubridade, de seis em seis meses. Por ocasião da cessação do contrato de trabalho, como já ocorreu na admissão, mas nas atividades a serem discriminadas em portaria, é, também, obrigatório exame médico (CLT, art. 168 e parágrafos). A abreugrafia será repetida a cada 2 anos (CLT, art. 168, §3ํㅜ). (NASCIMENTO, 2011, p. 850).

Assim, os exames demissionais poderiam prever a realização de teste de gravidez como uma forma de trazer segurança tanto 
para a gestante, como para o empregador, bem como evitar que o nascituro seja exposto a atividades que lhe causam prejuízos.

Vale citar o posicionamento de Sérgio Pinto Martins, citado por Celestino et al. (1996, p. 78), segundo o qual nada impede a empresa de exigir exame médico na dispensa da empregada visando verificar se esta se encontra grávida, justamente por ter o objetivo de manter a relação de emprego, caso o resultado venha a ser positivo.

Conforme Palmeira Sobrinho (2000, p. 37), se a empresa quiser se precaver contra uma possível surpresa, que decorra de uma gravidez, poderá, com fulcro no art. 168, II, da CLT (que dispõe sobre o exame demissional), proceder ao exame laboratorial capaz de atestar se a empregada encontra-se grávida para tomar as devidas providências.

Inclusive tramita o Projeto de Lei $n^{\circ} 6074 / 2016^{3}$, que trata da inclusão do parágrafo oitavo ao artigo 168 da CLT, tornando obrigatório o exame de gravidez por ocasião da dispensa da mulher.

Havendo a realização do teste, seria oportunizada ao empregador, de imediato, conforme prevê a norma, a possibilidade de reintegração da mulher ao emprego. Caso não fosse possível a reintegração, então o empregador procederia à indenização da gestante pelo seu período de estabilidade, mas teria a oportunidade de escolher entre as duas opções legais.

No entanto, da forma em que a norma tem sido interpretada, muitas vezes o empregador não consegue reintegrar à gestante ao emprego, não possuindo alternativa que não seja a indenização, possuindo um gasto elevado, pois não obterá a força de trabalho daquela empregada. As correntes protecionistas afirmam que essa possibilidade está compreendida dentro dos riscos do negócio, porém não é razoável incluir a má-fé de uma empregada que omite o fato de estar grávida para que possa auferir vantagens, tendo ainda a legislação trabalhista como sua aliada.

Desde 30/11/2017 aguarda parecer da Comissão de Constituição e Justiça e de Cidadania (CCJC). 
Nesse sentido vale ressaltar outra alteração que ocorreu com a reforma trabalhista, observando-se que a CTL, em seu art. 8으, passou a prever que o direito comum será fonte subsidiária do direito do trabalho. Assim, no tocante a esse abuso de direito, conforme Braiani (2005, p. 172) o art. 187, do Código Civil prevê que "[...] Também comete ato ilícito o titular de um direito que, ao exercê-lo, excede manifestamente os limites impostos pelo seu fim econômico ou social, pela boa-fé ou pelos bons costumes".

De acordo com Nascimento (2011, p. 1161), sob o ângulo empresarial, a estabilidade já representaria uma restrição ao poder diretivo, ao passo que o empregador se vê tolhido do seu direito de dispor livremente do empregado no momento em que julgar oportuno. No entanto, entre a liberdade do empresário e o direito do nascituro, não existe justificativa plausível para não proteger uma criança.

Ademais, conforme Celestino et al. (1997, p. 64), o pagamento do salário-maternidade, de responsabilidade da previdência social, só é garantido enquanto vigora o contrato de trabalho.

Conforme Brasil (2017a, paginação irregular), não estando a gestante trabalhando, é necessário comprovar a qualidade de segurada do INSS e, conforme o caso, cumprir carência de 10 meses trabalhados. Caso tenha perdido a qualidade de segurado, deverá cumprir metade da carência de 10 meses antes do parto/ evento gerador do benefício, consoante Lei no $13.457 / 2017$. Portanto, não ocorrendo a reintegração da gestante há o risco dela não perceber a licença-maternidade pela previdência.

Para a trabalhadora, a reintegração no emprego também parece ser a melhor alternativa, tendo em vista que a gestante que não está trabalhando pode perder alguns benefícios, especialmente o plano de saúde, se não tiver condições de permanecer pagando.

Além disso, o momento após o parto não parece ser o período adequado de se procurar um novo emprego, pois existe uma 
vida dependendo daquela mãe, que está com seu psicológico alterado e pode não conseguir este emprego, tendo em vista todo preconceito existente no mercado de trabalho.

0 que se pretende com essa pesquisa é encontrar o meio mais justo de equilibrar o direito das trabalhadoras com o das empresas, porém mais importante ainda é assegurar a empregada a possibilidade de manutenção do seu emprego e a consequente garantia de sobrevivência digna a ela e à criança, que é a finalidade que o legislador quis atribuir à norma em análise.

\section{A EXTENSÃO DO PERÍODO DE LICENÇA-MATERNIDA- DE COMO FORMA DE EFETIVAÇÃO DE UM MEIO AM- BIENTE DO TRABALHO SAUDÁVEL}

A licença-maternidade está prevista no artigo 71 e seguintes da lei 8.213/91. Apesar de o pagamento ser realizado pelo empregador, o custo da licença-maternidade é da Previdência Social, pois a empresa deduz os valores pagos à empregada gestante das contribuições que necessita realizar ao INSS. 0 artigo 201, inciso II, da CF apresenta como um dever da Previdência Social a proteção à maternidade.

Conforme Delgado (2014, p. 739), o salário-maternidade é a renda mensal correspondente à remuneração integral da trabalhadora gestante, paga por ocasião do período de afastamento previdenciário para o parto e aleitamento materno.

A lei $n^{\circ} 8.213 / 91$, em seu artigo 71-A, dispõe que, ao segurado ou segurada que adotar ou obtiver guarda judicial para fins de adoção de criança, também é devido salário-maternidade pelo período de 120 dias.

0 período de licença-maternidade pode ser estendido para 180 dias, nos casos em que a empresa aderir ao programa "Empresa Cidadã”, no qual a pessoa jurídica tributada com base no lucro real poderá deduzir do imposto devido, em cada período de apuração, o total da remuneração integral da empregada e 
do empregado pago nos dias de prorrogação de sua licença-maternidade/ paternidade.

Conforme acentuam Lazzarin e Santos:

Essa lei foi criada tendo como base dados da Sociedade Brasileira de Pediatria, os quais apontam que a amamentação regular, por seis meses, reduz dezessete vezes as chances de a criança contrair pneumonia, cerca de cinco vezes a possibilidade de anemia e cerca de duas vezes a ameaça de problemas intestinais. No período de prorrogação da licença, a empregada não poderá exercer qualquer atividade remunerada, e a criança não poderá ser mantida em creche ou organização similar, já que tais situações estariam contra o objetivo do programa. É importante referir que, ainda que a empresa tenha aderido ao Programa, é necessária a concordância da trabalhadora gestante. Quanto ao Programa, compreende-se que, com a intensa adesão a este, poderia haver uma redução dos custos relativos à saúde, já que esta faz parte do sistema da Seguridade Social no Brasil. (LAZZARIN; SANTOS, 2018, p. 78).

A Organização Mundial da Saúde (OMS) e o Ministério da Saúde recomendam o aleitamento materno exclusivo por seis meses e complementar até os dois anos ou mais. Segundo Kennedy (2005 apud BRASIL, 2009, p. 12), vários estudos sugerem que a duração da amamentação na espécie humana seja, em média, de dois a três anos, idade em que geralmente ocorre o desmame naturalmente.

No entanto, a legislação que possuímos acerca do tema refere que a mulher deverá ter assegurado o direito de amamentar seu filho durante o expediente até que o mesmo complete seis meses. Para tanto, contará com dois descansos especiais de meia hora cada um, conforme redação do art. 396, da CLT. Com a reforma trabalhista foi acrescentado o $\S 2^{\circ}$ deste artigo, que preceitua que os horários de descanso deverão ser definidos em livre acordo 
entre a mulher e o empregador. Contudo, com uma análise até mesmo superficial, percebemos a ineficiência deste artigo, na medida em que em uma cidade grande, por exemplo, meia hora é um período insuficiente para o deslocamento e concretização da amamentação ao filho(a) e os bebês não possuem horários regrados para mamar.

Por outro lado, a possibilidade de acordo poderia ser positiva, mas a grande maioria dos empregadores não respeita os empregados, tendo em vista serem a parte mais fraca da relação, dependentes diretamente de seus salários, retirando-lhes todos os direitos que possam ser acordados. Esta é uma grande crítica à nova legislação que, em diversos pontos, propõe a negociação entre patrão e empregado. Contudo, mesmo antes da reforma trabalhista, na prática, muitas trabalhadoras já negociavam com seus patrões esses períodos de descanso.

0 artigo da consolidação trabalhista ainda refere que o período de seis meses poderá ser dilatado conforme a saúde da criança requeira. Todavia, a legislação poderia ter sofrido um avanço, alterando-se o período de licença-maternidade para seis meses, que é o período em que a criança não deve receber qualquer outro tipo de alimentação a não ser o leite materno, conforme a recomendação oficial da Sociedade Brasileira de Pediatria e, após isso, ser permitido o aleitamento materno no local de trabalho até que a criança complete dois anos, em média.

Os estudos demonstram que, com a amamentação, são reduzidos inúmeros problemas que podem afetar as crianças, tais como diarreias, contração de doenças respiratórias e desnutrição. Conforme Bianca Bomfim (2013, p. 30), a amamentação ainda previne a obesidade, hipertensão, diabetes, doenças cardiovasculares, osteoporose e determinados tipos de câncer, promove a facilidade na digestão, desenvolve os músculos da face, sendo importante para o alinhamento adequado dos dentes, para o desenvolvimento da fala e estimulo da adequação a respiração, 
além de incentivar o desenvolvimento cognitivo e afetivo. Pensemos, pois, na quantidade de crianças que necessitam utilizar aparelhos dentários atualmente.

Ainda, de acordo com Bonfim (2013, p. 30), para a mãe, a amamentação auxilia a readaptação do útero ao seu tamanho normal e reduz a perda de sangue após o parto, diminuindo o risco de anemia, acelera a perda de peso, previne o câncer de mama, de endométrio e ovário, além de proporcionar um contato íntimo e prazeroso para a mãe e o bebê, o que possibilita que a mãe transfira seu amor e carinho ao filho, fazendo com que ele se sinta amado e seguro, o que promove o sucesso da amamentação e aumenta a autoestima da mulher.

Assim, o próprio empregador, ao permitir que sua empregada ofereça aleitamento materno ao seu filho durante o período recomendado pelo Ministério da Saúde, evitaria que a mesma fosse obrigada a ausentar-se do trabalho em seu retorno por causa da saúde fragilizada de seu bebê.

Conforme a pesquisa de campo realizada com profissionais da área da saúde, constante do Apêndice A, não existe contradição entre os entrevistados, todos concordam que a amamentação deve subsistir por seis meses, bem como apontam os benefícios que o leite materno traz para a criança.

Denota-se que a responsabilidade pelo pagamento da licença-maternidade é do Estado por ser a saúde da mulher e da criança motivo de interesse público (DELGADO, 2014, p. 840), e não do empregador na maioria dos casos, o que faz com que o aumento do período de licença-maternidade em 60 dias não seja mais um peso a ser suportado financeiramente pelo empregador.

Nesse sentido, a autora Cristiane M.S. Lopes, tece importantes considerações acerca das trabalhadoras-mães e de seus direitos: para se dispor a trabalhar e que a maternidade e os encargos familiares não gerem custo para 
as empresas é o objetivo mais premente e eficaz para combater a discriminação das mulheres no mercado de trabalho. Cada indivíduo tem o direito a dedicar-se a sua família e, ao mesmo tempo, de trabalhar. Por outro lado, o trabalho é também um dever, já que é a principal forma de obter as condições materiais de sobrevivência do (a) trabalhador (a) e daqueles que estão a seu cargo. Note-se que a lei impõe o dever de assistência recíproca para os membros de uma mesma família. Daí ser de fácil dedução que o direito ao trabalho (e o dever de trabalhar) deve ser exercido de forma que permita a compatibilização do direito de gozar a dignidade de estar em família e o dever de aportar recursos econômicos a essa mesma família. [...] Esse conjunto de direitos e deveres, porém, deve ser garantido pelo Estado. O Estado brasileiro é um Estado Social, pois se obrigou a apoiar as necessidades dos cidadãos, dentre as quais a de assistência à infância e à velhice. Com efeito, o Estado é responsável pela manutenção da seguridade social, o que implica a assunção de deveres relacionados com doença, idade avançada e maternidade. (LOPES, 2010, p. 44).

Diversos estudos mostram que o tempo mínimo de amamentação dos recém-nascidos é de seis meses e, quando a empresa adere ao programa "Empresa Cidadã", a licença-maternidade passa de quatro para seis meses. Assim, a licença-maternidade, de acordo com as orientações do próprio Ministério da Saúde, poderia passar a ser de 180 dias para todas as empresas, pois tal mudança contribuiria muito para a saúde dos bebês brasileiros.

É necessário ressaltar também que a Lei no 11.770/2008, que dispõe acerca da extensão da licença-maternidade, não é aplicável a todas as empresas, de acordo com Bonfim (2013, p. 30). Exemplo disso é que aquelas que se enquadram no SIMPLES (Sistema Integrado de Pagamento de Impostos e Contribuições das Microempresas e das Empresas de Pequeno Porte), bem como as que 
possuem tributação com base no lucro presumido, não poderão aderir ao programa Empresa Cidadã. Essa possibilidade até havia sido admitida pela redação original da lei, mas foi vetada. Assim, o resultado da proibição consiste, por um lado, no impedimento da criação uma modalidade de dedução do Imposto sobre a Renda da Pessoa Jurídica - IRPJ sem qualquer limite, conforme as razões do veto, mas, por outro lado, reduz a aplicabilidade prática do instituto de prorrogação da licença-maternidade.

Outro motivo pelo qual a licença-maternidade de 180 dias deveria ser estendida a todas as trabalhadoras do setor privado é o fato de o programa "Empresa Cidadã" não garantir efetivamente que as mulheres que trabalham nessas empresas venham a gozar da licença-maternidade estendida. Isso porque, de acordo com Bianca Bomfim (2013, p. 32), a gestante poderá ficar com receio de sofrer assedio moral no trabalho caso goze a licença-maternidade de 180 dias, e assim, deixe de requerê-la. Existe até mesmo a possibilidade das empresas coagirem as empregadas para que não requeiram a extensão, gozando apenas dos benefícios do programa, sem concretizar a finalidade do mesmo.

As mulheres que necessitam retornar ao trabalho e ainda estão amamentando precisam ter diversos cuidados para que não ocorra o desmame dos bebês, necessitando congelar o seu próprio leite materno para poder oferecer aos filhos, o que não pode ser através de mamadeiras, pois elas são muito diferentes do seio materno, devendo ser utilizados copinhos e colherinhas, conforme explica a pediatra especialista em comportamento do bebê, Luciana Herrero (2015, paginação irregular). Muitas mulheres sequer têm conhecimento de que a mamadeira gera o desmame de seus filhos.

Outra situação desconfortável que as mulheres que voltam ao trabalho amamentando são submetidas é o fato de necessitar desprezar parte do seu leite para se sentirem um pouco mais confortáveis, porém ordenhar o leite é recomendável pelos pro- 
fissionais como forma de estimular a produção de leite materno, bem como evitar problemas como a mastite e o abcesso, porém isso deveria ocorrer naturalmente com a amamentação da criança. Apesar de todas essas dificuldades, a mulher ainda não pode se estressar, pois o stress faz com que a produção de leite diminua.

É importante ressaltar que já existe um projeto de lei em tramitação que propõe a alteração dos artigos 392 da CLT e 71 e 71-A, da Lei 8.213/91, promovendo a ampliação da licença- maternidade para 180 dias para todas as empresas do setor privado, bem como pretende alterar a legislação para permitir ao pai da criança acompanhar a mãe em todas as consultas médicas. Trata-se do projeto de lei no 72 , de 2017, proposto pela Senadora Rose de Freitas (MDB-ES), que já foi aprovado em sua casa de origem, o Senado Federal, e atualmente se encontra na Câmara dos Deputados. 0 referido projeto foi objeto de consulta pública realizada através do site do Senado Federal, onde 576 pessoas apoiaram a proposição, enquanto 29 demonstraram não concordar com o referido projeto. (BRASIL, 2017b, paginação irregular).

Comparando o direito brasileiro com o de outros países, a Desembargadora do Tribunal Regional do Trabalho do Rio de Janeiro (TRT-RJ), Vólia Bomfim, em entrevista, declarou que são 34 países que cumprem a recomendação da Organização Internacional do Trabalho (OIT) de conceder ao menos 14 semanas de licença-maternidade, dentre eles o Brasil. Mas, de acordo com ela, a maioria das mulheres no mundo ainda não tem essa proteção. Ela cita países da África e da Ásia. Como os mercados mais avançados neste quesito, Vólia aponta o Reino Unido, que concede 315 dias de licença-maternidade. Já a Suécia, permite que as mães fiquem afastadas do trabalho por 240 dias para ficar junto com seus bebês. Esse prazo pode ser maior em outros países, como é o caso da Albânia e Montenegro, ambos no sudeste da Europa, onde a licença-maternidade chega a um ano. Não obstante, para a desembargadora, a aprovação do projeto de lei no 72 de 2017 
deveria ser postergada para uma fase econômica melhor do país, tendo em vista o momento de retração da economia que tem sido vivenciado (LFG, 2018, paginação irregular).

Os críticos da ampliação deste direito às gestantes afirmam que seria reduzida a igualdade entre homens e mulheres no mercado de trabalho, mas, como visto acima, existem diferenciações necessárias, as quais garantem um meio ambiente de trabalho saudável e proporcionam a permanência das mulheres no mercado. Vale frisar, conforme Bonfim (2013, p. 32) que, quando a Constituição de 1988 estabeleceu o período de 120 dias de licença-maternidade os críticos utilizaram-se do mesmo argumento de discriminação da mulher e o que se notou foi o contrário, com as mulheres conquistando cada vez mais postos de trabalho. Essa diferença biológica entre homens e mulheres existe, mas não será ela que irá impedir o avanço das mulheres, até porque é válido lembrar que todos dependem das gestantes para que a nossa espécie continue existindo.

Lazzarin e Santos (2018, p. 85) defendem que, para dissipar essa diferenciação entre homens e mulheres, a licença-maternidade e paternidade deveriam ser concedidas em períodos iguais, equiparando-as. Contudo, não concordamos com tal premissa que, apesar de realmente igualar ambos, é desnecessária para os homens, tendo em vista que não dão à luz e nem amamentam, não se justificando um período tão extenso de licença. Não estaríamos tratando de uma igualdade material, conforme as diferenciações biológicas exigem, mas de uma igualdade formal, que apenas oneraria mais o empresariado. 0 que é desigual, verdadeiramente, é existir um determinado período de licença-maternidade para certas empregadas e outro para outras empregadas na mesma situação.

Diante da extensão do período de licença-maternidade surge um problema relacionado com a estabilidade da gestante, analisada no tópico acima. Com o período normal de licença de 120 
dias a mulher retorna ao emprego e ainda possui um mês de estabilidade, não podendo ser demitida. Com a licença-maternidade de 180 dias a mulher fica desamparada pela estabilidade, tendo em vista que a lei 11.770/08 nada dispõe sobre isso, e pode ser demitida mesmo em casa, sem justa causa. Nesse ponto, seria muito interessante o aumento da estabilidade, ao passo que este é um momento muito delicado da vida de uma mulher, como já referido. Partilhamos, pois, do pensamento de Celestino et al (1997, p. 80), que dispõe que os homens deveriam expandir o prazo de estabilidade da mulher, tomando por conta o exemplo da estabilidade do acidentário, que vai até um ano após o término do auxílio-doença.

0 art. 400 da CLT especifica como devem ser os locais da empresa destinados à guarda dos filhos das empregadas que ainda estejam sendo amamentados. Eles deverão possuir, no mínimo, um berçário, uma saleta de amamentação, uma cozinha dietética e uma instalação sanitária. É nesse local que, atualmente, as mães amamentam seus filhos até que completem seis meses de idade. No entanto, conforme Lopes:

Não causará surpresa a ninguém o fato de que essa norma, de uma maneira geral, simplesmente não é cumprida. Ambiente de trabalho e recém-nascidos não combinam na cultura empresarial brasileira. E a mulher-mãe, que acaba de retornar ao trabalho, no final de seu período de estabilidade no emprego, não tem a mínima condição de exigir a satisfação desse direito pelo patrão. Tampouco se tem noticia de que haja fiscalização do cumprimento deste dispositivo, mesmo porque, a própria lei autorizou substituir o "local apropriado para guardar crianças e amamentar" por creches distritais. Restará a mulher que amamenta pleitear a redução de uma hora em sua jornada de trabalho ou, então, pleitear judicialmente o pagamento de uma hora extraordinária por dia trabalhado, sem 
a concessão dos dois intervalos de trinta minutos. (LOPES, 2010, p. 53).

Portanto, temos aqui mais motivos que justificam a extensão do período de licença-maternidade para seis meses. Com relação à possibilidade da mulher pleitear o pagamento de horas extras no caso de não concessão dos intervalos para amamentação, vislumbramos também a pretensão de indenização por danos morais a essa trabalhadora que se viu impedida de amamentar seu próprio filho pelo ato ilícito do empregador, destacando-se que esse momento da vida da criança não poderá ser "repetido ou consertado" com o simples pagamento de horas extraordinárias.

A empresa que permite que seus empregados possam estabelecer um equilíbrio entre suas vidas profissionais e pessoais certamente contará com uma mão-de-obra mais engajada, produtiva e satisfeita, além de um meio ambiente do trabalho mais saudável, com menos faltas ao serviço.

Conforme o entrevistado (a) 1 da pesquisa realizada com médicos obstetras, ginecologistas e pediatras, poderia haver uma forma de licença-maternidade estendida e flexível, onde a licença legal de 120 dias contaria com mais três meses, que seria um período adaptativo, onde a mulher poderia escolher entre se reintroduzir na empresa, com carga horária reduzida e home office em alguns dias da semana.

É sabido que a lei sofre alterações ao longo do tempo, acompanhando a evolução social. Com a licença-maternidade não é diferente: ocorreu a sua ampliação ao longo dos anos por ter se percebido a importância deste período de convivência entre a mãe e o bebê. Prova disso é que a CLT, no art. 392 previa 12 semanas de licença e o referido artigo foi revogado pela Constituição de 1988, que, no art. 7º, inciso XVIII, passou a prever o período de 120 dias. 0 mesmo ocorreu com relação à licença-paternidade, que anteriormente não existia, mas, com 
o reconhecimento da importância da responsabilização paterna na criação dos filhos, foram editadas leis neste sentido. Assim, a ampliação da licença maternidade seguramente seria um avanço na legislação com relação às gestantes.

\section{DAS MUDANÇAS ADVINDAS COM A REFORMA TRA- BALHISTA: POSSIBILIDADE DAS GESTANTES TRABALHA- REM EM AMBIENTES INSALUBRES}

Com relação ao trabalho da mulher durante o período gestacional, antes da reforma trabalhista, a gestante não poderia trabalhar em local insalubre em qualquer grau, conforme a antiga redação do art. 394-A, da CLT.

0 artigo supra referido foi alterado, de forma que atualmente as gestantes somente deverão ser afastadas das atividades insalubres em grau máximo. Nas atividades consideradas insalubres em grau médio ou mínimo, a gestante apenas será afastada quando apresentar atestado médico que recomende o afastamento durante a gestação.

Conforme Natália Lemos Mourão (2017, p. 114), fazendo-se uma análise aprofundada através de um estudo comparativo entre a legislação antiga e a nova, percebe-se que a alteração foi muito grave, na medida em que traz prejuízos não apenas à empregada gestante, mas, principalmente à criança, submetendo ambas ao risco de morte.

Conclui sabiamente a autora na análise do tema:

O espírito de amparo a trabalhadora não está presente nessa Reforma, pois de acordo com o que prescreve a atual legislação, permite-se que a gestante labore em ambiente insalubre, caso não haja perigo para ela e o seu bebe. Indaga-se: como o médico de confiança chegará a essa conclusão? Ele vai se dirigir até o local de trabalho da gestante? E se o médico der o diagnóstico errado e a criança nascer com sequelas? Haverá perícia? E se a perícia for falha? (MOURÃO, 2017, p. 114). 
Portanto, verificou-se uma intenção clara do legislador em limitar os direitos dos trabalhadores, submetendo-os às mais penosas condições de trabalho, também trazendo riscos à saúde do nascituro. No entanto, em pontos que poderiam ser regulados de forma a trazer maior segurança jurídica ao ordenamento, não houve qualquer discussão ou alteração, como a inclusão do exame de gravidez dentre os exames demissionais, conforme anteriormente discutido. É possível que isso tenha ocorrido, pois tal alteração não seria de todo ruim para as empregadas gestantes, visto que seria uma forma de garantir a sua permanência no emprego. Já para a retirada crua de direitos, a reforma trabalhista não dispersou esforços.

Dizer que a gestante poderá ser submetida ao trabalho insalubre em grau médio e mínimo significa admitir a possibilidade das mulheres grávidas laborarem com ruído contínuo e intermitente, ruído de impacto e exposição ao calor superiores aos limites de tolerância, além de radiações não-ionizantes, vibrações, frio, umidade, agentes químicos e agentes biológicos, conforme a Norma Regulamentadora - NR 15, que dispõe sobre as atividades e operações insalubres.

Importante referir que a proteção das gestantes e lactantes com a proibição do trabalho em ambientes insalubres não era uma norma antiga em nossa legislação, na medida em que foi introduzida na CLT com a Lei 13.287, de 2016, que havia acrescentado o art. 384-A, que, conforme sua antiga redação, assegurava a empregada gestante e lactante o afastamento de quaisquer atividades, operações ou locais insalubres enquanto durasse a gestação. Portanto, a partir desta alteração de 2016, as gestantes e lactantes deveriam permanecer em locais salubres, livres de agentes nocivos.

Conforme Duarte Neto (2018, p. 164), à época, tal artigo causou discussões sobre sua aplicação prática, tendo em vista que entrou em vigor na data de sua aplicação, não dispondo de 
um período de adaptação para os empregadores. Outro ponto controverso era de que o referido artigo não deixava claro se era o empregador quem realizaria o pagamento do adicional de insalubridade quando a gestante permanecesse afastada.

Neste ponto, a nova redação do art. 394-A, §§ $2^{\circ}$ e $3^{\circ}$, da CLT, deixou claro que cabe a empresa pagar o adicional de insalubridade a gestante ou lactante, efetivando-se a compensação dos valores com as contribuições que a empresa deveria realizar ao INSS e, caso seja hipótese de afastamento por não existir na empresa local salubre para o labor da gestante, como ocorre nos hospitais, haverá a percepção de salário-maternidade também pelo INSS.

Aqui, é possível observar um avanço da reforma trabalhista, dentre tantas inovações prejudiciais. Isto porque, conforme Duarte Neto (2018, p. 165), a nova regulamentação busca evitar prejuízo financeiro para as empregadas gestantes, já que poderão continuar recebendo o adicional de insalubridade durante o período de afastamento, considerando que o referido adicional tem natureza de salário-condição, que pode ser suprimido quando desaparecidas as circunstâncias que justificam seu pagamento, sem implicar ofensa ao principio da irredutibilidade salarial. Portanto, neste ponto específico, trata-se de uma norma de proteção às gestantes e ao nascituro.

Neste sentido, conforme Almiro Eduardo de Almeida:

Se ainda aceitamos que o ser humano seja empregado como meio e que atribuamos, não valores, mas propriamente preços à sua vida, integridade física e saúde, temos, ao menos, que pagar o quanto lhe é devido, respeitando a lógica mercadológica do sistema que adotamos. (ALMEIDA, 2016, p.115).

Inclusive, é importante referir que o artigo 394-A, com a sua antiga redação de 2016, que não deixava claro de quem era 
a responsabilidade do pagamento, foi objeto de ação direta de inconstitucionalidade perante o Supremo Tribunal Federal por parte da Confederação Nacional de Saúde, Hospitais e Estabelecimentos e Serviços (CNS), a qual recebeu o número 5.605. Foi utilizado o argumento de que a norma ofendia os princípios da livre-iniciativa, do livre exercício da profissão e da igualdade de gêneros. A confederação argumentou ainda que a referida norma discriminou as gestantes.

A referida ADIN ainda está em tramitação perante o Supremo Tribunal Federal. Contudo, tais argumentos não prosperariam. Conforme Izabel Christina Baptista de Queiroz Ramos (2018, p. 162), nesse caso não existe violação ao princípio da isonomia, mas sim atendimento às peculiaridades da empregada mulher, grávida ou lactante, que apresenta momentaneamente justificativa para receber tratamento diferenciado na relação de emprego, com o objetivo de proteção a valores maiores. A proibição antes existente no art. 394-A tratava-se de uma norma de saúde pública.

Por sua vez, dispõe Duarte Neto:

Ocorre que o direito a livre iniciativa deve ser analisado e interpretado conjuntamente com princípios tais quais o da dignidade da pessoa humana e o da proteção à vida, e até mesmo o princípio da função social da propriedade, o que afasta a ideia de uso absoluto da empresa por seu proprietário. [...] Disso decorre, inclusive, a indisponibilidade absoluta desse direito, ainda que sob o argumento da liberdade de exercício da profissão, uma vez que a saúde da trabalhadora gestante e, muito especialmente, a do nascituro, não constitui valor sujeito à autonomia contratual. (DUARTE NETO, p. 164).

Mesmo assim, o artigo recém-modificado foi alterado novamente pela reforma trabalhista de 2017, trazendo uma redação totalmente contrária a inicialmente produzida, na medida em que 
anteriormente possuía exacerbada preocupação com as gestantes em local insalubre, afastando-as de todos os graus de insalubridade e, com a redação atual, as gestantes somente serão afastadas dos locais insalubres em grau máximo. Com relação à insalubridade em grau médio e mínimo elas somente serão afastadas caso apresentem atestado de saúde que recomente o afastamento, o qual será produzido por um médico de sua confiança e não pelo médico do trabalho, que seria o profissional adequado a avaliar o ambiente de trabalho.

De acordo com Ramos:

\begin{abstract}
Diante de tantas alterações seguidas do mesmo dispositivo, nos perguntamos o que poderia ter mudado nas condições fáticas relacionadas à proteção à maternidade e ao nascituro, que justificasse a novel permissão legislativa, a vigorar a partir de novembro/2017, em autorizar o trabalho da gestante e lactante em condições insalubres, como regra, havendo a exceção da proibição médica.

Certamente, nada se alterou, na medida em que a mulher continua acumulando as funções produtiva e reprodutiva, assim como a carta constitucional estabelece a proteção à maternidade (art. 6ํㅜ e 7으, $\mathrm{XX)}$ e o princípio da prioridade na proteção integral do menor (art. 227). (RAMOS, 2018, p. 160).
\end{abstract}

A alteração ocorrida foi muito prejudicial às gestantes e aos nascituros. E, ainda, analisando os artigos da reforma trabalhista de forma sistêmica, verificamos, no artigo 611-A, XII, da CLT, a possibilidade da convenção coletiva de trabalho e do acordo coletivo de trabalho "acordarem" o enquadramento do grau de insalubridade. Portanto, pensemos no caso de uma gestante cuja categoria tenha acordado anteriormente baixar o grau de insalubridade do seu ambiente de trabalho e depois venha a gestar uma criança, ela não terá o afastamento imediato de seu local de trabalho insalubre em grau máximo, pois este, mesmo sendo 
faticamente um ambiente insalubre em grau máximo, será tido para todos os efeitos, como o ambiente insalubre no grau que a CCT ou ACT definirem.

Desta forma, essa gestante, mesmo submetida aos riscos de um local insalubre em grau máximo, apenas poderá afastar-se obtendo atestado médico, o que pode demorar a ocorrer. Na mesma linha do pensamento de Ramos (2018), também se questiona o que haveria de se alterar no ambiente insalubre antes considerado em um determinado grau, que agora, por um acordo entre patrão e sindicatos ou entre as duas categorias, passe a ter um grau diferente, sem a análise do médico especialista em segurança do trabalho, que seria a única pessoa apta a auferir o grau de insalubridade do ambiente. E mesmo esse profissional, conforme bem ressaltou o entrevistado (a) 1 da pesquisa de campo, poderá ter uma conduta inadequada por possuir vínculo com a empresa.

Nesse sentido, conforme Montal (2018, p. 126), vale referir que a CLT prevê a necessidade de perícia técnica para a aferição do grau de insalubridade no artigo 195, este, por sua vez, não revogado pela reforma trabalhista. Deste modo, há aqui pontos, no mínimo, contraditórios. 0 mesmo ocorre com relação ao artigo 190 da lei trabalhista, que refere que o Ministério do Trabalho e Emprego é o responsável por aprovar o quadro de atividades e condições insalubres, os critérios de caracterização da insalubridade e os limites de tolerância aos agentes nocivos.

Portanto, primeiramente indaga-se: como seria possível os sindicatos poderem acordar com o empregador o nível de insalubridade a que os empregados serão submetidos, sem possuir o conhecimento técnico inerente? Da mesma forma, quais serão as consequências de uma gestante que acordou previamente o seu nível de insalubridade, continuar laborando durante sua gestação e lactação neste ambiente "reenquadrado"?

Por conseguinte, por diversos ângulos que se pretenda olhar para a alteração que a reforma proporcionou ao art. 394-A, não 
se encontram motivos plausíveis para a flexibilização da saúde das gestantes e dos bebês. Não há crise econômica que justifique sacrificar a saúde daqueles que sequer podem se posicionar, pois ainda nem tiveram a chance de nascer com vida, apesar de possuírem seus direitos a salvo desde a concepção, conforme art. $2^{\circ}$ o do Código Civil, o que é totalmente desrespeitado por esta nova redação dada pela reforma.

Neste sentido, conforme visto anteriormente, outro dispositivo incluído pela reforma trabalhista, o art. 8ํㅗ $\$ 1^{\circ}$, dispõe que o direito comum será fonte subsidiária da legislação do trabalho. Portanto, com a novel legislação, há previsão da aplicação dos dispositivos do CC e, neste caso, existe uma colisão entre o previsto na CLT e no CC, na medida em que um protege e o outro relativiza o direito do nascituro. Quando essa colisão ocorre, é aplicado o disposto na CLT, mas será deixada de lado essa disposição de proteção aos bebês sedimentada ao longo de anos no Código Civil?

A referida norma, com a sua atual redação, também tem sido objeto de inúmeros questionamentos pelos estudiosos do direito do trabalho e, até mesmo pelo próprio relator do projeto de lei da reforma trabalhista. Conforme Duarte Neto:

Tal norma, o que desde já se compreende, tem sido objeto de forte questionamento, inclusive quando o projeto de lei tramitou no Senado Federal, o seu relator, embora tenha concluído pela não modificação do texto aprovado pela Câmara dos Deputados, casa de origem, registrou entender equivocado o dispositivo, curiosamente "sugerindo" ao Presidente da República o "conserto" por meio de Medida Provisória ou veto. (DURTE NETO, 2018, p. 164).

Neste sentido, de acordo com Siqueira e Maranhão (2017, p. 90), o legislador inverteu o ônus de avaliação técnica dos riscos labor-ambientais, sendo que eventual quadro de agressividade à 
saúde humana deve ser identificado e tecnicamente comprovado pela obreira mediante atestado médico. Para o autor, o legislador ampliou os riscos psicossociais incidentes sobre a trabalhadora que se encontra nessa delicada situação, de forma que muitas mulheres acabarão optando por permanecer no labor, apesar do atestado médico recomendar o contrário, com medo de represálias ou más compreensões da chefia.

É extremamente grave a alteração ocorrida no ordenamento jurídico, sobretudo porque a lei dita as normas da vida de milhares de pessoas e é feita para ser seguida. Interpretações podem ser feitas sobre a lei, mas elas partem do conteúdo da norma, que, no caso, é muito prejudicial. De acordo com Radbruch:

Ordens são ordens, é a lei do soldado. A lei é a lei, diz o jurista. No entanto, ao passo que para o soldado a obrigação e o dever de obediência cessam quando ele souber que a ordem recebida visa à prática de um crime, o jurista, desde que há cerca de cem anos desapareceram os últimos jusnaturalistas, não conhece exceções deste gênero à validade das leis nem ao preceito de obediência que os cidadãos lhes devem. A lei vale por ser lei, e é lei sempre que, como na generalidade dos casos, tiver do seu lado a força para se fazer impor. Esta concepção da lei e sua validade, a que chamamos Positivismo, foi a que deixou sem defesa o povo e os juristas contra as leis mais arbitrárias, mais cruéis e mais criminosas. Torna equivalentes, em última análise, o direito e a força, levando a crer que só onde estiver a segunda estará também o primeiro. (RADBRUCH, 1979, p. 415).

Assim, de acordo com Ramos:

Diante disso, e para que se procedesse a nova alteração da legislação infraconstitucional, retirando a proteção da gestante e lactante, seria mister 
um estudo técnico a respeito, que comprovasse a desnecessidade do instituto para proteção a maternidade, ou até mesmo oitiva da sociedade envolvida que legitimasse a alteração promovida pela reforma trabalhista da Lei 13.467/2017, e nada disso foi apresentado pelo legislativo. (RAMOS, 2018, p. 162).

Ademais, conforme Montal (2017), a mudança prejudicial ocorrida viola o princípio da não-regressividade dos direitos sociais e trabalhistas.

Dessa forma se verifica o quão grave são as consequências da aprovação de uma reforma como ocorreu, sem debates por parte de estudiosos da matéria, em caráter de urgência, sem uma análise de suas consequências.

Contudo, diante do atual cenário, o melhor a ser feito é o estudo dos riscos a que estão sendo submetidas às gestantes. Por isso foi realizada pesquisa de campo com profissionais da área da saúde, como médicos ginecologistas, obstetras e pediatras, os quais provavelmente serão os denominados "médicos de confiança da mulher". Como se pode observar no Apêndice A, há divergência entre os especialistas. Enquanto dois deles entendem que a norma é prejudicial à gestante e ao nascituro, não só pelos próprios riscos inerentes ao ambiente insalubre, mas também pelo estresse que aquela mãe passaria por ter que submeter o seu filho a condições inadequadas, existem outros que alegam que o bebê estaria protegido pelas barreiras protetoras que a mãe fornece, não vislumbrando problemas em fornecer atestado médico para uma trabalhadora laborar nestas condições. Assim, com médicos com pensamentos divergentes, não será respeitado o princípio da isonomia com relação às trabalhadoras, sendo algumas submetidas ao trabalho insalubre durante a gestação e outras não.

Com relação ao conhecimento técnico acerca do ambiente insalubre, todos concordam que o médico especialista em segurança 
do trabalho é o mais apto a avaliar as condições do ambiente de trabalho, concordando que o ginecologista/obstetra/médico de confiança da mulher não possui plenas condições de fornecer o atestado sem a vistoria do local de trabalho. Conforme o entrevistado (a) 2, o obstetra daria seu atestado com base no grau de insalubridade auferido pelo médico do trabalho.

Com a presente pesquisa de campo verificou-se que realmente quem arcará com o ônus de levar as informações acerca da insalubridade do seu local de trabalho para o médico será a gestante. E se ela não fizer isso procurando manter o emprego?

Da mesma forma, conforme os dados obtidos na entrevista, mesmo que o bebê possua relativa proteção, a mulher grávida ainda continua desprotegida, assim concluímos que a alteração é uma regressão do direito.

No entanto, sempre é possível encontrar alternativas no ordenamento jurídico. Nesse sentido, é mister ressaltar que, conforme o art. 394, da CLT, mediante atestado médico, à mulher grávida é facultado romper o compromisso resultante de qualquer contrato de trabalho, desde que este seja prejudicial à gestação. Ela poderá fazer isso através do instituto da rescisão indireta, com fulcro no art. 483, "c", da CLT (SIQUEIRA; MARANHÃO, 2017, p. 89). Desta forma, diante da alteração ocorrida ainda existe uma forma de dirimir os riscos, porém é inegável que houve retrocesso no direito das gestantes.

\section{CONSIDERAÇÕES FINAIS}

Os direitos das gestantes são extremamente necessários para a permanência das mulheres no mercado de trabalho, posto que as mães necessitam conciliar a sua vida particular - o que inclui a maternidade como um dos acontecimentos mais marcantes com o emprego e, sem a proteção conferida por certos institutos, isso se tornaria muito mais angustiante para essas trabalhadoras. 
A estabilidade e a licença-maternidade são conferidas em um momento onde a mulher se encontra mais fragilizada emocionalmente e, até mesmo, financeiramente, pois aquela vida agora dependerá de seus genitores para suprir as suas necessidades materiais e emocionais. Portanto, no sentido material, a estabilidade no emprego é muito importante. No sentido emocional, destacamos a extensão da licença-maternidade como uma forma de contribuir para a relação entre mãe e filho. Apesar das reconhecidas dificuldades que todas as mulheres enfrentam, tais institutos não podem conferir às gestantes mal intencionadas uma forma de abuso de direito, sob pena de prejudicar a todas as mulheres-mães que se encontram no mercado de trabalho lutando por seus direitos.

Para tentar solucionar esta questão, com vistas à concretização também de um meio ambiente do trabalho mais seguro, propomos a realização de exames demissionais mais completos, o que traria mais segurança jurídica para todos, principalmente para a mãe e o bebê. Ressaltamos que a Lei 9.029/95 proíbe apenas a realização de exames de gravidez na contratação e permanência da trabalhadora no emprego, portanto, na demissão não há que se falar em permanência da relação de trabalho. Todavia, mesmo a lei não proibindo tal prática, seria mais interessante uma regulamentação neste sentido, afirmando categoricamente essa possibilidade e garantindo efetivamente o direito à reintegração, que é da gestante e do empregador. Como ficou ressaltado, já existe o projeto de lei no $6074 / 2016$, com vistas à inclusão do teste de gravidez quando ocorrer a dispensa de mulheres.

Ponto mais importante ainda diz respeito à saúde das gestantes e dos nascituros, no qual não se pode admitir nenhum tipo de relativização. Nesse sentido, a norma que possibilita o trabalho e aleitamento materno em locais insalubres deveria ser objeto de inconstitucionalidade, retomando-se a redação original da lei de 2016, com a proibição total do trabalho das gestantes em 
ambientes insalubres. Por outro lado, também visando à saúde dos nascituros e suas mães, a discussão acerca da ampliação da licença-maternidade para seis meses é extremamente oportuna e vem sido debatida há tempos. Dessa forma, já foram amplamente comprovados por órgãos respeitados, como o Ministério e a Organização Mundial da Saúde, os benefícios que tal direito traria a toda sociedade, bastando apenas a aprovação do projeto de lei no 72, de 2017.

Por fim, conclui-se que as normas atualmente postas em nosso ordenamento jurídico trabalhista, apesar de já terem avançado muito, não asseguram completamente a manutenção de um meio ambiente do trabalho seguro e saudável. Nesse sentido ainda é necessária uma evolução, principalmente diante das últimas alterações da reforma trabalhista. Entende-se que, adotando as medidas acima, já estaríamos contribuindo para um grande avanço nessa matéria. Como alternativa, caso não ocorra a mudança na lei, propõe-se o ajuizamento de rescisões indiretas no caso da gestante ser submetida a riscos devido ao trabalho insalubre, com fulcro nos artigos 394 e 483, "c", da CLT.

\section{REFERÊNCIAS}

ALMEIDA, Almiro Eduardo de. Para um meio ambiente de trabalho saudável e sem riscos: ou quanto custa causar danos à saúde e colocar em risco a vida do trabalhador. LTr Suplemento Trabalhista, São Paulo, v. 52, n. 114, p. 671-679, dez. 2016.

BARROS, Alice Monteiro de. Curso de direito do trabalho. 6. ed. São Paulo: LTr, 2010.

BONFIM, Bianca. A ampliação da licença-maternidade repercussões sociais e jurídicas: trabalho e direitos: conquistas e retrocessos em debate. Rio de Janeiro: Lumen Juris, 2013. p. 29-36.

BRASIL. Ato das Disposições Constitucionais Transitórias. Diário Oficial [da] República Federativa do Brasil. Poder Executivo, Brasília, DF, 1988. Disponível em: < http://www.planalto.gov.br/ccivil_03/constituicao/constituicao.htm>. Acesso em 10 jun. 2018. 
BRASIL. Constituição da República Federativa do Brasil de 1988. Diário Oficial [da] República Federativa do Brasil. Poder Executivo, Brasília, DF, 1988. Disponível em: < http://www.planalto.gov.br/ccivil_03/ constituicao/constituicao.htm>. Acesso em 10 jun. 2018.

BRASIL. Decreto Lei ${ }^{\circ} 5.452$, de $1^{\circ}$ de maio de 1943. Aprova a Consolidação das Leis do Trabalho. Diário Oficial [da] República Federativa do Brasil. Poder Executivo, Brasília, DF, 1943. Disponível em: < http:// www.planalto.gov.br/ccivil_ 03/decreto-lei/Del5452.htm>. Acesso em 10 jun. 2018.

BRASIL. Instituto Nacional do Seguro Social (INSS). Salário-maternidade. Brasília, DF: INSS, 05 nov. 2017a. Disponível em: <https://www. inss.gov.br/beneficios/salario-maternidade/>. Acesso em: 04 nov. 2018.

BRASIL. Lei $\mathrm{n}^{\circ}$ 8.213, de 24 de julho de 1991. Dispõe sobre os Planos de Benefícios da Previdência Social e dá outras providências. Diário Oficial [da] República Federativa do Brasil. Poder Executivo, Brasília, DF, 1991. Disponível em: < http://www.planalto.gov.br/ccivil_03/leis/ L8213cons.htm>. Acesso em 10 jun. 2018.

BRASIL. Lei no 11.770, de 9 de setembro de 2008. Cria o Programa Empresa Cidadã, destinado à prorrogação da licença-maternidade mediante concessão de incentivo fiscal, e altera a Lei no 8.212, de 24 de julho de 1991. Diário Oficial [da] República Federativa do Brasil. Poder Executivo, Brasília, DF: 2008. Disponível em: < http://www.planalto. gov.br/ccivil_03/_Ato2007-2010/2008/Lei/L11770.htm>. Acesso em: 19 jun. 2018.

BRASIL. Lei no 9.029, de 13 de abril de 1995. Proíbe a exigência de atestados de gravidez e esterilização, e outras práticas discriminatórias, para efeitos admissionais ou de permanência da relação jurídica de trabalho, e dá outras providências. Diário Oficial [da] República Federativa do Brasil. Poder Executivo, Brasília, DF, 1995. Disponível em: < http://www.planalto.gov.br/ccivil_03/LEIS/L9029.HTM>. Acesso em: 10 jun. 2018.

BRASIL. Ministério da Saúde. Saúde da criança: nutrição infantil: aleitamento materno e alimentação complementar. Brasília: Editora do Ministério da Saúde, 2009.

BRASIL. Senado Federal. Projeto de Lei do Senado $\mathbf{n}^{\circ}$ 72, de 2017. Altera os arts. 392 da Consolidação das Leis do Trabalho (CLT), aprovada pelo Decreto-Lei no 5.452, de 1o de maio de 1943, 71 e 71-A da Lei no 8.213, de 24 de julho de 1991, para majorar o prazo da licença- 
-maternidade, de 120 para 180 dias, e permitir ao pai acompanhar a mãe do nascituro nas consultas e exames durante a gravidez. Brasília, DF, 2017b. Disponível em: <https://www25.senado.leg.br/web/atividad e/materias/-/materia/128502>. Acesso em 25 out. 2018

CASTRO. Mariana Mader Pires de. Tudo que você precisa saber sobre licença-maternidade. In: Blog CordVida. 07 fev. 2018. Disponível em: <http://www.cordvid a.com.br/blog/tudo-que-voce-precisa-saber-sobre-licenca-maternidade/>. Acesso em: 07 jun. 2018.

CELESTINO, Carla A. F. V. et al. A despedida arbitrária da empregada gestante suas consequências. Revista do Tribunal Regional do Trabalho da 19 Região, Maceió, v. 4, n. 1, p. 60-81, jan./dez., 1997.

CUNHA, M. I. M. S. A. Direito do Trabalho. 3 ed. rev. e atual. São Paulo: Saraiva, 2004.

D’AMBROSO. Marcelo José Ferlin. Cinco minutos de filosofia do direito e a reforma trabalhista. [S.l.:S.n.], 2017. Disponível em: <http://csb. org.br/wp-content/uploads/2017/10/Marcelo-DAmbroso-artigo-cinco-minutos-de-filosofia-do-Direito-e-a-reforma-trabalhista.pdf > Acesso em: 11 jun. 2018.

DELGADO, Mauricio Godinho. Curso de direito do trabalho. 13 ed. São Paulo: Ltr, 2014.

DUARTE NETO, Bento Herculano. 0 trabalho da gestante em atividades insalubres e as inovações introduzidas pela reforma trabalhista: direito do trabalho e processo do trabalho: reforma trabalhista: principais alterações. São Paulo: LTr, 2018.

HERRERO, Luciana. Amamentação e trabalho: 10 dicas de sucesso. In: Youtube, 01 ago. 2015. Disponível em: <https://www.youtube.com/ watch?v=go2tHchl2OU> Acesso em: 25 out. 2018.

HERRERO, Luciana. Amamentação e trabalho: como oferecer o leite materno ao bebê sem causar o desmame. In: Youtube, 01 ago. 2015. Disponível em: <https://www.youtube.com/watch?v=DVpv1mtfXk8>. Acesso em: 25 out. 2018.

HERRERO, Luciana. Amamentação e trabalho: os piores palpites. In: Youtube, 01 ago. 2015. Disponível em: <https://www.youtube.com/ watch?v=0T7ebt0UQQI>. Acesso em: 25 out. 2018.

INSTITUTO BRASILEIRO DE GEOGRAFIA E ESTATÍSTICA (IBGE). Estatísticas de Gênero. Brasília, DF: IBGE, 2010. Disponível em: <https:// 
www.ibge.gov. br/apps/snig/v1/?loc $=0 \&$ cat $=-1,1,2,-2,-3,128 \&$ ind $=4727>$. Acesso em: 10 jun. 2018.

KODAMA, Teresa Cristina Della Monica. OAB: cartilha de orientação sobre os direitos trabalhistas da mulher. São Paulo: OAB, 2012.

LÁ VEM BEBÊ. Saiba como ficam os direitos da gestante na reforma trabalhista. 02 jan. 2018. Disponível em: <https://lavembebe.com.br/ blog/direitos-da-gestante-reforma-trabalhista/>. Acesso em: 07 jun. 2018.

LAZZARIN, Helena Kugel; SANTOS, Goddman Andrade. A (des)proteção à maternidade e à paternidade na legislação laboral brasileira. Revista Fórum Justiça do Trabalho, Belo Horizonte, v. 35, n. 409, p. 73-89, jan. 2018.

LFG. Projeto de lei amplia licença-maternidade para 180 dias. 2018. Disponível em: <https://www.lfg.com.br/conteudos/noticias/geral/ projeto-de-lei-amplia-licenca-maternidade-para-180-dias $>$ Acesso em: 25 out. 2018.

LOPES, Cristiane Maria Sbalqueiro. A efetivação do direito à creche no Brasil. Revista do Ministério Público do Trabalho, Brasília, v. 20, n. 40, p. 38-60, set. 2010.

MONTAL, Zélia. 0 labor da gestante e da lactante em ambientes insalubres: proibição de regressividade de direitos. Reforma trabalhista em debate: direito individual, coletivo e processual do trabalho. São Paulo: LTr, 2017.

MOURÃO, Natália Lemos. 0 excesso da tutela estatal e a proteção do trabalho da mulher gestante. Revista de Direito do Trabalho, São Paulo, v. 181, ano 43, p. 99-116, set. 2017.

NASCIMENTO, Amauri Mascaro. Curso de direito do trabalho: história e teoria geral do direito do trabalho: relações individuais e coletivas do trabalho. 26. ed. São Paulo: Saraiva, 2011.

PALMEIRA SOBRINHO, Zéu. A estabilidade da empregada gestante. Síntese Trabalhista, Porto Alegre. v. 12, n. 135, p.35-40, set. 2000. R5533.

PEREIRA, Emmanoel. A estabilidade da gestante na Justiça do Trabalho. Revista do Tribunal Superior do Trabalho, Brasília, v. 83, n. 1, p. 37 43, jan./mar. 2017.

PINTO, Raymundo. Uma análise da reforma trabalhista sem radicalismos. LTr Suplemento Trabalhista, São Paulo, v. 54, n. 5, p. 21-26, mar. 2018. 
RAMOS, Izabel Christina Baptista Queiróz. A reforma trabalhista e o trabalho da mulher: reforma trabalhista na visão dos procuradores do trabalho. Salvador: JusPodivm, 2018.

RIO GRANDE DO SUL. Tribunal Regional do Trabalho da 4a Região. Acórdão $\mathrm{n}^{\circ}$ 0021261-54.2015.5.04.0003. Primeira Turma. TRT4, Porto Alegre, 06 jul. 2017. Relatora Lais Helena Jaeger Nicotti. Disponível em: <https://www.trt4.jus.br/pesqu isas/rest/cache/acordao/pje/41M9gg 3ex5ud1NjX4BZnvg/?\&tp=gestante+a\%C3\%A7\%C3\%A3o+ap\%C3\%B3 s+a+estabilidade>. Acesso em: 07 jun. 2018.

RIO GRANDE DO SUL. Tribunal Regional do Trabalho da 4a Região. Acórdão $n^{\circ}$ 0020586-80.2015.5.04.0233. Décima Primeira Turma. TRT4, Porto Alegre, 25 maio 2018. Relatora Maria Helena Lisot. Disponível em: <https://www.trt4.jus.br/pesquis as/rest/cache/acordao/pje/cb tCV8nbWkkRYwA7berW3g? \&tp=gestante+a\%C3\%A7\%C3\%A3o+ap \% C3\%B3s+a+estabilidade>. Acesso em: 07 jun. 2018.

RIO GRANDE DO SUL. Tribunal Regional do Trabalho da 4a Região. Acórdão $\mathrm{n}^{\circ}$ 0021654-11.2015.5.04.0251. Primeira Turma. TRT4, Porto Alegre, 31 ago. 2017. Relatora Iris Lima de Moraes. Disponível em: <https://www.trt4.jus.br/pesquisa s/rest/cache/acordao/pje/uU DlpupaltFq53XuzvrFPw?\&tp=gestante+indeniza\%C3\%A7\%C3\%A3o+a p\%C3\%B3s+um+ano>. Acesso em: 09 jun. 2018.

RIO GRANDE DO SUL. Tribunal Regional do Trabalho da 4a Região. Acórdão $n^{\circ}$ 0021284-84.2016.5.04.0772. Primeira Turma. TRT4, Porto Alegre, 10 maio 2018. Relatora Lais Helena Jaeger Nicotti. Disponível em: <https://www.trt4.jus.br/pes quisas/rest/cache/acordao/ pje/zzPLldAo-4yCGO6XG1uWRA?\&qp=gestante+ajui zamento+da+a\% C3\%A7\%C3\%A3o+ap\%C3\%B3s+um+ano+do+nascimento+do+filho $>$. Acesso em: 09 jun. 2018.

RIO GRANDE DO SUL. Tribunal Regional do Trabalho da 4a Região. Acórdão $\mathrm{n}^{\circ}$ 0021378-05.2016.5.04.0102. Primeira Turma. TRT4, Porto Alegre, 22 fev. 2018. Relatora Lais Helena Jaeger Nicotti. Disponível em: <https://www.trt4.jus.br/pesqui sas/rest/cache/acordao/pje/ $\mathrm{k} 4 \mathrm{lZdnFPC2QRlu}$ jjj5c6cg? \&qp=gestante+ajuizamento+da+a\%C3\%A7 $\% \mathrm{C} 3 \% \mathrm{~A} 3 \mathrm{o}+\mathrm{ap} \% \mathrm{C} 3 \% \mathrm{~B} 3 \mathrm{~s}+\mathrm{um}+\mathrm{ano}+\mathrm{do}+$ nascimento $+\mathrm{do}+$ filho $>$. Acesso em: 09 jun. 2018.

SIQUEIRA, Carlos Eduardo; MARANHÃO, Ney Stany Morais. Trabalho de gestantes e lactantes em atividade insalubre: comentários críticos ao Novo Art. 394-A da CLT abordagem médico-jurídica. São Paulo : LTr, 2017. 
Anexo a - TERMO DE CONSENTIMENTO LIVRE E ESCLARECIDO (TCLE)

Projeto: É POSSÍVEL UTILIZAR OS DIREITOS DAS GESTANTES COMO FORMA DE CONCRETIZAR UM MEIO AMBIENTE DO TRABALHO SAUDÁVEL? Uma análise da legislação existente sobre o tema e das mudanças advindas com a reforma trabalhista

Você está sendo convidado (a) a participar da pesquisa acima, cujo objetivo é obter a opinião de especialistas acerca da possibilidade admitida pela reforma trabalhista das gestantes laborarem em locais insalubres em grau médio e mínimo mediante a apresentação de atestado de seu médico de confiança, bem como sobre a lactação em todos os níveis de insalubridade. Também serão coletados dados acerca do aleitamento materno no local de trabalho. 0 contato se dará através de meios digitais. Assim, primeiramente será feita a abordagem dos médicos através de suas redes, com o convite para participação na pesquisa. Após o aceite, será enviado por e-mail o questionário estruturado, bem como o presente termo. 0 participante da pesquisa deverá assinar o TCLE e enviar à pesquisadora, respondendo, em seguida, ao questionário aplicado, também por meio digital. A participação dos médicos no estudo será de risco mínimo, visto que serão realizadas entrevistas. Algum constrangimento poderá ocorrer ao responder a entrevista, visto que, até mesmo, são perguntadas opiniões pessoais dos especialistas. $\mathrm{Na}$ ocorrência destes, a pesquisadora se compromete a interromper a entrevista e conversar com o profissional de forma acolhedora, também através das plataformas digitais ou até mesmo por telefone, relembrando o caráter voluntário de sua participação. Quanto aos benefícios, o estudo não trará benefícios diretos aos participantes, mas poderá contribuir para a qualificação do trabalho no local de estudo, assim como para a sociedade, que poderá avaliar se existem riscos com a aplicação da nova legislação para as mulheres gestantes. A sua participação ajudará no desenvolvimento de novos conhecimentos, que poderão eventualmente beneficiar você e outras pessoas no futuro.

Os seus registros serão sempre tratados confidencialmente. Os resultados deste estudo poderão ser usados para fins científicos, mas você não será identificado (a) por nome. Sua participação no estudo é voluntária, de forma que, caso você decida não participar, isto não afetará no tratamento normal que você tem direito. Você não terá custo nem receberá por participar. Sua participação não é obrigatória e, a 
qualquer momento, você poderá desistir e retirar seu consentimento. Sua recusa não trará nenhum prejuízo em relação ao pesquisador ou com a instituição.

Caso você tenha dúvidas ou solicite esclarecimentos, entrar em contato com o pesquisador responsável professora Maria Claudia Felten, telefone (51) 984047904, com a acadêmica Luisa da Rosa Moccellin, telefone (51) 32267429 ou (51) 997820532, ou com o Comitê de Ética em Pesquisa do Centro Universitário Metodista - IPA pelo telefone (51) 3316.1237.

Assinatura do participante da pesquisa:

Assinatura do pesquisador responsável:

Assinatura do pesquisador auxiliar:

Data:__/____-_

Observação: 0 presente documento baseado no item IV das Diretrizes e Normas Regulamentadoras para a pesquisa em saúde, do Conselho Nacional de Saúde (resolução 466/12), será assinado em suas vias, de igual teor, ficando uma via em poder do paciente ou de seu representante legal e outra com o pesquisador responsável.

APÊNDICE A - ENTREVISTA APLICADA AOS PROFISSIONAIS DA SAÚDE E RESPOSTAS OBTIDAS APRESENTADAS DE FORMA SIGILOSA

Prezados,

Estou confeccionando meu trabalho de conclusão de curso (TCC), ao qual atribui a seguinte intitulação: "É POSSÍVEL UTILIZAR OS DIREITOS DAS GESTANTES COMO FORMA DE CONCRETIZAR 
UM MEIO AMBIENTE DO TRABALHO SAUDÁVEL? Uma análise da legislação existente sobre o tema e das mudanças advindas com a reforma trabalhista".

Por conseguinte, o tema do meu TCC consiste em analisar os direitos que as mulheres possuem atualmente no ordenamento jurídico com relação à maternidade, como o período de licença de 120 dias (a efetividade deste período e a possibilidade de sua extensão para seis meses) e o intervalo para amamentação, bem como os direitos modificados com a reforma trabalhista (a possibilidade das gestantes trabalharem em ambientes insalubres em grau médio e mínimo com o fornecimento de um atestado de saúde pelo seu médico de confiança).

Antes da reforma trabalhista, a gestante não poderia trabalhar em local insalubre em qualquer grau, conforme a antiga redação do art. 394-A, da CLT.

Dizer que a gestante poderá ser submetida ao trabalho insalubre em grau médio e mínimo significa admitir a possibilidade das mulheres grávidas laborarem com ruído contínuo e intermitente, ruído de impacto e exposição ao calor superiores aos limites de tolerância, além de radiações não-ionizantes, vibrações, frio, umidade, agentes químicos e agentes biológicos, conforme a Norma Regulamentadora - NR 15, que dispõe sobre as atividades e operações insalubres.

Por isso, faz-se necessária a presente pesquisa de campo, com a obtenção da opinião de especialistas acerca do tema, com o objetivo de verificar se a mudança ocorrida é prejudicial às mulheres e crianças e, da mesma forma, com relação ao aleitamento materno.

A pesquisadora informa que todos os dados informados pelos médicos serão tratados com total confidencialidade, devendo-se destacar que os resultados serão apresentados de forma global.

Após a conclusão da pesquisa e sua homologação pelo Centro Universitário Metodista - IPA, caso seja do interesse do profis- 
sional participante da pesquisa, terei o maior prazer em enviar uma cópia do trabalho.

A participação de cada médico convidado é vital para o sucesso do trabalho, na medida em que apenas com os dados científicos informados pelos profissionais será possível chegar a uma conclusão acerca dos riscos existentes no trabalho insalubre para as gestantes e bebês, portanto, contamos com a sua adesão ao trabalho.

Qualquer dúvida quanto ao questionário ou outras informações sobre o trabalho, não hesitem em contatar-me.

Desde já, agradeço a sua participação.

Atenciosamente,

Luisa da Rosa Moccellin. 


\section{PERGUNTAS:}

Considerando à alteração da legislação trabalhista no que diz respeito ao trabalho da empregada gestante em ambientes insalubres em grau médio e mínimo, há algum risco a gestante ou ao feto com a mudança da lei?

ENTREVISTADO (A) 1: Colocar a gestante em local que oferece riscos ao trabalhador por meio da presença de agentes agressivos à saúde e expor a mesma às agentes de risco - acima dos limites de tolerância de insalubridade previstos na NR 15- é um equívoco grave não só para a saúde dela, como para o bebê em formação em seu útero. A gestante exposta a estes ambientes sofre duplamente: pelos efeitos diretos dos agentes agressivos em seu corpo, como também, emocionalmente, estresse, por estar expondo seu filho em formação à problemas sérios de saúde.

ENTREVISTADO (A) 2: 0 feto apresenta duas barreiras protetoras que a mãe fornece, não para ela, e sim apenas para o nascituro: a barreira placentária, que filtra a maior parte dos substâncias tóxicas, medicações e agentes biológicos que possam atingir o feto, e o líquido amniótico, que fornece uma barreira mecânica contra impactos, atenuação de ruídos e estabilização de temperatura. Desta forma, um ambiente insalubre para a gestante é muito menos insalubre para o feto, ou seja, a gestante é uma mulher normal grávida, não podendo ser considerada a gravidez como uma doença, ou um estado significativamente frágil para a mulher. Se assim não fosse, as agricultoras e índias, exemplificando, teriam uma taxa de patologias obstétricas maior que as grávidas mais protegidas, o que não é verdadeiro.

ENTREVISTADO (A) 3: Depende de qual fator de riscos ela for exposta, no caso dos ruídos, já é comprovado que o feto escuta os sons que vem do ambiente externo desde as 18 semanas de gestação. E a continuidade desses poderia prejudicar o bebê em algum grau. 
Na qualidade de médico de confiança de uma gestante submetida a estas condições, o senhor (a) se sentiria confortável em lhe fornecer um atestado que indicasse a possibilidade de trabalho em ambiente insalubre (médio e mínimo)?

ENTREVISTADO (A) 1: Ao não possuir especialidade de Medicina do trabalho, e portanto, não conhecer a fundo os reais riscos que estaria submetendo a grávida e o bebê em formação, não me sinto em condição de oferecer tal parecer.

ENTREVISTADO (A) 2: Sim, pelos motivos apontados no item 1.

ENTREVISTADO (A) 3: Não, quem tem que conceder esse atestado é o médico do trabalho da empresa e não o médico obstetra.

O ginecologista possui plenas condições de analisar se a gestante pode laborar em ambiente insalubre em grau médio ou mínimo sem vistoriar o ambiente de trabalho?

ENTREVISTADO (A) 1: Não. Mesmo se vistoriasse não teria condições adequadas pois não cursou a especialidade necessária

ENTREVISTADO (A) 2: Não. O grau de insalubridade do ambiente de trabalho deve ser indicado pelo médico do trabalho, sendo que o obstetra daria sua conduta baseado nesta indicação.

ENTREVISTADO (A) 3: Não, como disse na resposta anterior isso é função da medicina do trabalho.

Qual a diferença entre o ginecologista e o médico especialista em segurança do trabalho?

ENTREVISTADO (A) 1: Medicina do trabalho é a especialidade médica que lida com as relações entre homens e mulheres trabalhadores e seu trabalho, visando não somente a prevenção dos acidentes e das doenças do trabalho, mas a promoção da saúde e da qualidade de vida. Ginecologia é a especialidade da medicina que lida diretamente com a saúde do aparelho reprodutor feminino e mamas.

ENTREVISTADO (A) 2: 0 obstetra, e não o ginecologista, supervisiona e orienta a gestação contra possíveis patologias 
maternas e fetais; o médico do trabalho supervisiona a relação de saúde entre o trabalhador e seu ambiente de trabalho.

ENTREVISTADO (A) 3: 0 obstetra acompanha a gestação e faz o parto e médico do trabalho é o que avalia as condições da empresa e funcionários.

Quais prejuízos podem ser causados à lactação o trabalho em ambiente insalubre em qualquer grau?

ENTREVISTADO (A) 1: Não saberia referir, pois seguramente cada ambiente nocivo causaria um risco específico. Contudo, genericamente, podemos afirmar que um ambiente insalubre causa estresse. E que o estresse inibe a produção de ocitocina, que é responsável pela ejeção do leite materno.

ENTREVISTADO (A) 2: Qualquer ambiente de trabalho que não seja confortável à mãe, não o será ao recém-nascido. Desta forma, tal ambiente deverá ser silencioso, ou pouco barulhento, com iluminação suave e temperatura e acomodações agradáveis; ao contrário, poderá haver prejuízos na produção de leite ou irritação maior do recém-nascido.

ENTREVISTADO (A) 3: A lactação deve ocorrer em ambiente o mais calma possíveis. Ambientes insalubres podem prejudicar a interação mãe e bebê.

Na sua opinião, é importante amamentar os recém-nascidos até os seis meses de idade? Quais benefícios a amamentação pode trazer ao bebê nessa faixa etária? Existem benefícios também para as mães?

ENTREVISTADO (A) 1: A amamentação é a alimentação padrão ouro para lactentes. Não apenas por conter na dose correta tudo o que bebê necessita para crescer forte, como também, por ser o único alimento que oferece a proteção imunológica para a criança. Ele é uma substancia viva que se adequa as necessidades do bebê. Pesquisas já comprovaram que centenas de doenças seriam prevenidas se a criança fosse amamentada. E que a criança que é amamentada - especialmente, de forma exclusiva até 6 
meses e continuada após a introdução alimentar, até 2 anos ou mais, como preconiza a OMS e o Ministério da Saúde Brasileirotem maiores taxa de QI (quociente intelectual) e características pessoais de maior autoconfiança.

A mãe também é extremamente beneficiada com esta prática, reduz chance de câncer de mama, de ovário, sangramento pós-parto. Além de diversas outras doenças. Ajuda, até, na redução de peso, a emagrecer no pós-parto.

ENTREVISTADO (A) 2: 0 ideal é que a amamentação dure por no mínimo 6 meses, visto o leite materno transferir anticorpos e reforçar o vínculo psicológico entre mãe e filho.

ENTREVISTADO (A) 3: Sim é importante. O aleitamento exclusivo permite uma melhor interação mãe e bebê é o alimento mais completo para a criança até os 6 meses. E ainda, quando exclusivo, funciona como método anticoncepcional e ajuda na perda de peso.

Comente o tipo de alimentação que é recomendada pelos especialistas até que a criança complete seis meses. É indicado introduzir outros tipos de alimento antes que a criança complete seis meses de idade?

ENTREVISTADO (A) 1: A recomendação oficial é aleitamento materno até 6 meses e complementado por outros alimentos até 2 anos ou mais. Na ausência deste tipo de nutrição, com perdas no quesito imunológico e vínculo afetivo, recomenda-se a introdução de fórmulas lácteas. Elas são bem inferiores ao leite materno, apesar do preço exorbitante. Não existe nada atualmente que se equivalha ao leite humano!

ENTREVISTADO (A) 2: Quanto à introdução de outros alimentos até os 6 meses de idade, não há consenso entre os pediatras: há os que acreditam que a amamentação deva ser exclusiva e tem os que acreditam que a partir dos 3 meses as crianças apresentam ganhos com a introdução de outros alimentos, visando estimular o paladar e a musculatura envolvida na deglutição. 
ENTREVISTADO (A) 3: A Sociedade Brasileira de Pediatria recomenda aleitamento exclusivo até os 6 meses e introdução alimentar somente após isso.

Quais os desafios que uma lactante enfrenta ao estar trabalhando durante o período de amamentação, considerando que ela possui direito a dois intervalos de trinta minutos para essa finalidade durante a sua jornada de trabalho. Como ela deverá proceder no local de trabalho para fornecer alimentação adequada ao seu bebê?

ENTREVISTADO (A) 1: O retorno ao trabalho para a nutriz (mulher que amamenta) é um enorme desafio. Por diversas questões:

-Evitar redução da produção do leite e evitar inflamações mamárias (mastite) por estar longe de seu bebê várias horas por dia. Para isto a nutriz deve estimular a mama e ordenhar quando esta estiver ingurgitada (pedrada, muito cheia). Estando no horário do café ou não. Aproximadamente a cada 3 horas. Se não houver um ambiente propício, a pia do banheiro pode ser usada para desprezar o leite que está em excesso no seio, que causa dor e desconforto, podendo levar a problemas mamários mais graves como mastite e abcesso.

-Estresse emocional pós-retorno ao trabalho: a volta ao trabalho, o excesso de cobrança dos chefes e colegas para que a nutriz tenha a mesma produtividade -ou ainda maior-pode ocasionar estresse intenso, fazendo que, muitas vezes, a mulher repense a vida profissional. Este estresse altera toda a bioquímica cerebral feminina, o que acaba prejudicando o rendimento no trabalho e a amamentação, pois há redução do hormônio ocitocina.

-Quem vai cuidar da criança: um outro fator extremamente estressante para a mulher no retorno ao trabalho é a quem vai delegar os cuidados do bebê? Creche ou cuidador? Cuidador é qualificado? Esta é uma das questões mais difíceis que interfere 
na produtividade laboral, faz repensar a manutenção na vida profissional e certamente, interfere na qualidade da amamentação.

ENTREVISTADO (A) 2: 0 desafio que se apresenta a uma mãe lactando é decorrendo do seu local de trabalho, sendo que ambientes que causem stress importante ou que não apresentem um clima tranquilo e confortável acarretará uma diminuição na produção de leite.

ENTREVISTADO (A) 3: A questão logística é a principal, pois embora ela tenha esse direito nem sempre terá alguém para trazer a criança até ela para amamentar, ou mesmo terá condições de ir até a criança. Seja essa uma questão de tempo, tráfego e condições sociais de pagar por esse deslocamento.

Na sua opinião, os direitos que as mulheres gestantes possuem atualmente (afastamento dos locais insalubres em grau máximo, afastamento dos locais insalubres em grau mínimo e médio mediante atestado de saúde, e dois intervalos de $30 \mathrm{mi}$ nutos para amamentação) são suficientes para garantir um meio ambiente do trabalho saudável às gestantes e seus bebes?

ENTREVISTADO (A) 1: A questão de permitir o trabalho das mulheres grávidas e puérperas (enquanto amamentarem) em locais insalubres - independentemente do grau de insalubridade é em minha opinião um crime, não só contra a saúde da trabalhadora e de seu rebento, mas, contra a saúde da sociedade. Permitir o adoecimento destas, em prol de uma maior produtividade e lucro das empresas é dar um tiro no próprio pé. As crianças de hoje são a força produtiva de amanhã. Sou totalmente contra esta alteração na legislação. Um médico, seja generalista ou até especialista em ginecologia, não tem as condições necessárias para analisar, com propriedade, a insalubridade de um posto de trabalho. Atenção deve ser tomada, pois, até mesmo o próprio especialista, o médico de trabalho, pode agir de forma inadequada, por ter vínculo pessoal com a empresa. 
Os outros direitos da mulher trabalhadora, tais como: tempo de licença-maternidade, intervalos para amamentar e auxílio creche, são positivos. Mas, ao meu ver insuficientes. Não resolvem as questões levantadas acima. Inserir a nutriz em um ambiente de trabalho nocivo, com agentes prejudiciais a ela, e que certamente, em muitos casos passaram pelo leite para o bebê, só irá piorar ainda mais o quadro tão delicado, prejudicando a vida e saúde da mulher e da criança. Sugestões:

-Que as empresas tenham um programa de educação e cuidado para com trabalhadoras gestantes e puérperas tardias (são as mulheres após o retorno ao trabalho até o sétimo mês de vida do bebê). Neste programa, deverá conter informações sobre saúde da gestante e da criança. E apoio para o sucesso da amamentação.

- Manter o intervalo para amamentação, dando a opção para a mulher escolher entrar mais tarde ou sair mais cedo, caso more longe e não tenha como trazer o bebê para amamentar durante a jornada de trabalho - o que já acontece em muitas empresas e instituições!

- As empresas contarem, obrigatoriamente com uma sala para apoio à amamentação. Já existe de forma espontânea em várias empresas. Esta saleta não só seria o local onde a mulher pudesse amamentar, caso haja a possibilidade de o bebê vir até o local de trabalho. Como também, seria o espaço adequado para que ela possa retirar o excesso de leite das mamas (ordenhar) e armazenar, para poder levar este leite para casa, para que possa ser oferecido ao bebê, nos momentos de ausência materna. Evitaria que a nutriz recorresse à pia do banheiro (lugar contaminado e público) para esvaziar as mamas no momento de dor e desconforto. Preveniria os incidentes de molhar as roupas por excesso de leite, o ingurgitamento das mamas e a própria mastite!

-Licença-maternidade estendida e flexível- sugerimos a criação de uma forma de licença-maternidade. As mulheres, nutrizes 
ou não, após cumprir a licença-maternidade legal de 120 dias, teriam mais três meses de período adaptativo: fase onde poderiam escolher se gostariam de se reintroduziriam na empresa, com opção de redução de carga horária diária e de trabalho home office em alguns dias por semana.

ENTREVISTADO (A) 2: Sim, desde que respeitadas as condições explicitadas no item anterior.

ENTREVISTADO (A) 3: Eles são conquistas importantes, mas ainda não resolvem de forma global. Toda Gestante deveria ser avaliada de forma individualizada pela medicina do trabalho para ser adequada a uma função que não prejudique o decorrer da gravidez. 